\title{
Comparison of effects of dietary coconut oil and animal fat blend on lactational performance of Holstein cows fed a high-starch diet
}

\author{
M. Hollmann and D. K. Beede ${ }^{1}$ \\ Department of Animal Science, Michigan State University, East Lansing 48824
}

\begin{abstract}
Dietary medium-chain fatty acids $\left(\mathrm{C}_{8: 0}\right.$ through $\left.\mathrm{C}_{12: 0}\right)$ are researched for their potential to reduce enteric methane emissions and to increase $\mathrm{N}$ utilization efficiency in ruminants. We aimed to 1) compare coconut oil ( $\mathrm{CNO} ; \sim 60 \%$ medium-chain fatty acids) with a source of long-chain fatty acids (animal fat blend; AFB) on lactational responses in a high-starch diet and 2) determine the effect of different dietary concentrations of $\mathrm{CNO}$ on dry matter intake (DMI). In experiment 1, the control diet (CTRL) contained (dry basis) $40 \%$ forage $(71 \%$ corn silage, and alfalfa hay and haylage), $26 \% \mathrm{NDF}$, and $35 \%$ starch. Isonitrogenous treatment diets contained $5.0 \%$ of $\mathrm{AFB}$ (5\%-AFB), $\mathrm{CNO}(5 \%-\mathrm{CNO})$, or a 1-to-1 mixture of $\mathrm{AFB}$ and $\mathrm{CNO}$ (5\%-AFB-CNO) and $0.8 \%$ corn gluten meal in place of corn grain. Thirty-two multiparous dairy cows $(201 \pm$ $46 \mathrm{~d}$ postpartum; $42.0 \pm 5.5 \mathrm{~kg} / \mathrm{d} 3.5 \%$ fat-corrected milk yield) were adapted to CTRL, blocked by milk yield, and randomly assigned to 1 of 4 treatment diets for $21 \mathrm{~d}$ with samples and data collected from d 15 through 21. Treatment 5\%-CNO decreased DMI markedly and precipitously and was discontinued after $\mathrm{d} 5$. In wk 3,5\%-AFB and especially 5\%-AFB-CNO lowered total-tract NDF digested vs. CTRL (2.6 vs. 1.8 vs. $3.1 \mathrm{~kg} / \mathrm{d}$, respectively), likely because fat treatments reduced DMI and 5\%-AFB-CNO impaired total-tract NDF digestibility. Milk fat concentrations were $3.10 \%$ (CTRL), $2.51 \%$ (5\%-AFB), and 1.97\% (5\%-AFB-CNO) and correlated negatively to concentrations of $\mathrm{C}_{18: 2 \text { trans- }}$ ${ }_{10, \text { cis- } 12}$ in milk fat. Additionally, 5\%-AFB and 5\%-AFBCNO tended to lower milk yield and decreased yields of solids-corrected milk and milk protein compared with CTRL. Fat treatments decreased milk lactose concentration, but increased milk citrate concentration. Moreover, cows fed 5\%-AFB-CNO produced less solids-corrected milk than did cows fed 5\%-AFB. In experiment 2, diets similar to CTRL contained 2.0, 3.0, or $4.0 \%$ CNO. Fifteen multiparous cows $(219 \pm 42 \mathrm{~d}$
\end{abstract}

Received August 1, 2011.

Accepted October 22, 2011

${ }^{1}$ Corresponding author: beede@msu.edu postpartum; $42.1 \pm 7.0 \mathrm{~kg}$ milk yield; mean $\pm \mathrm{SD}$ ) were blocked by DMI and randomly assigned to 1 of 3 treatment diets for an 8-d evaluation. Dietary concentration of CNO affected DMI, with the greatest depression at $4.0 \%$ CNO. Overall, dietary CNO depressed DMI and NDF digestibility of a high-starch diet compared with AFB. Feeding CNO to lactating cows equal to or greater than $2.5 \%$ decreased lactational performance or DMI.

Key words: fatty acid, fat source, lactational performance, dietary starch

\section{INTRODUCTION}

Inclusion of saturated medium-chain fatty acids (MCFA, $\mathrm{C}_{8: 0}$ through $\mathrm{C}_{12: 0}$ ) in ruminant diets is being explored as a means to decrease enteric methane emissions and enhance $\mathrm{N}$ utilization efficiency (Hristov and Jouany, 2005). However, 4 challenges to the use of MCFA in ruminant diets have been described. First, dietary MCFA can decrease DMI and energy intake in diets in which MCFA partially replace grain (Jordan et al., 2006; Faciola et al., 2008) and also when MCFA replace long-chain fatty acids (LCFA), such as stearic acid $\left(\mathrm{C}_{18: 0}\right.$; Külling et al., 2002; Dohme et al., 2004) or an animal-vegetable oil blend (Reveneau, 2008). Another potential challenge is that total-tract NDF digestibility (NDFD) can be depressed concurrently with decreased DMI, especially at increased dietary MCFA concentrations (Jordan et al., 2006; Reveneau, 2008). Decreased NDFD can lower the rate of NDF passage from the reticulorumen, increase ruminal fill, and thus may, in part, explain DMI depression. Depressed intake and NDFD in ruminants can counteract the potential benefits of dietary MCFA to decrease enteric methane emissions and to improve efficiency of $\mathrm{N}$ utilization in praxis.

A third potential challenge is that dietary MCFA often cause milk fat depression (MFD; Faciola et al., 2008; Reveneau, 2008; Hristov et al., 2011). Diets with greater ruminal fermentability, such as high dietary starch concentration (e.g., $>30 \%$, dry basis), low NDF concentration (e.g., $<28 \%$ ) or digestibility, and a more fermentable forage source (e.g., corn silage compared 
with alfalfa), generally increase the risk of MFD (Lock et al., 2006; Staples, 2006). Finally, inclusion of dietary fats can change the fatty acid (FA) composition of milk fat. Dietary lauric $\left(\mathrm{C}_{12: 0}\right)$ and myristic $\left(\mathrm{C}_{14: 0}\right)$ acids increase their respective proportion in milk FA (Odongo et al., 2007; Reveneau, 2008; Hristov et al., 2011). Increasing $\mathrm{C}_{12^{-}}$or $\mathrm{C}_{14^{-}} \mathrm{FA}$ in human diets may increase plasma cholesterol concentrations and, thus, is considered potentially undesirable in human nutrition (Grundy, 1994).

The mechanism(s) by which dietary MCFA influence DMI, NDFD, and MFD need to be more clearly characterized and defined. The effects of MCFA likely differ from those of unsaturated LCFA (Reveneau, 2008). Furthermore, the dietary concentration at which MCFA influence DMI is not clear. A highly fermentable diet presents an opportunity to compare the potentially different mode of action(s) of MCFA with unsaturated LCFA on lactational performance (e.g., DMI, NDFD, or MFD). Moreover, a highly fermentable diet allows comparison of the extent of MFD in cows fed MCFA diets with that of cows fed diets containing unsaturated LCFA. Importantly, replacing a starch source in highly fermentable diets with a fat source reduces ruminally available starch and potentially could alleviate ruminal acidosis and MFD (Hollmann et al., 2011). In turn, potentially less magnitude of change in milk fat concentration exists if dietary MCFA are added to an already milk fat-depressing diet. Additionally, diets with high ruminal availability of starch lead to the generation of more propionate, which competes for hydrogen ions with methanogens (McAllister et al., 1996). Thus, theoretically, high-starch diets could accentuate methane reduction with dietary MCFA.

The overall goal of our research is to determine the basis for the effects of dietary MCFA on DMI and MFD in high-producing cows to overcome limitations to use of dietary MCFA to reduce methane emissions and improve $\mathrm{N}$ utilization efficiency. The initial goal of the current study was to compare dietary MCFA with LCFA in a high-starch diet to assess the effects of FA chain length and characterize MFD. Thus, our first objective (experiment 1) was to characterize DMI and lactational performance with dietary inclusion of MCFA versus LCFA. We hypothesized that 1) inclusion of dietary fats would decrease DMI, but not energy intake and lactational performance and 2) dietary MCFA versus LCFA would decrease energy intake and lactational performance, and would affect the FA profile of milk. Fat sources to supply MCFA and LCFA were coconut oil (CNO) and animal fat blend (AFB), respectively. Subsequently, our second objective (experiment 2) was to assess DMI in lactating cows fed different concentrations of CNO. We hypothesized that increased dietary
MCFA concentrations from CNO would progressively decrease DMI.

\section{MATERIALS AND METHODS}

The All University Committee on Animal Use and Care at Michigan State University approved all experimental procedures (Approval 06/07-096-00).

\section{Cows and Treatments}

Experiment 1. Thirty-two multiparous Holstein cows (201 \pm 46 DIM; mean \pm SD) from the Michigan State University Dairy Teaching and Research Center were used. Cows were fed a single basal adjustment diet without supplemental fat or monensin for $28 \mathrm{~d}$ before initiation of experiment. Baseline values of lactational performance were established during the last $7 \mathrm{~d}$ of that period; cows yielded $42.0 \pm 5.5 \mathrm{~kg} / \mathrm{d}$ of $3.5 \% \mathrm{FCM}$ (mean $\pm \mathrm{SD}$ ). Cows were blocked by baseline $3.5 \%$ FCM yield and assigned to 1 of 4 treatment diets in a randomized block design. The experimental period lasted $21 \mathrm{~d}$. Treatments were a control diet (CTRL) that did not contain any added fat and 3 treatment diets, in which $5.0 \%$ added fat (dry basis) replaced ground corn. Dietary treatments with added fats were $5.0 \%$ AFB (5\%-AFB), $5.0 \%$ CNO (5\%-CNO), and a 1-to-1 mixture by weight of AFB and CNO (5\%-AFBCNO). Mixes included corn gluten meal to balance for and maintain dietary $\mathrm{CP}$ concentration in all diets. Fat treatments were premixed with concentrate (non-forage) feeds. Coconut oil was heated to $40^{\circ} \mathrm{C}$ before mixing to increase its fluidity, whereas AFB was added to the concentrate mixture at ambient temperature. Feed was mixed daily from concentrate premixes and forages and offered as a TMR. Ingredients and analyzed chemical compositions of experimental diets are in Table 1. Laboratory analysis revealed that starch concentration in CTRL was 34.8\% (dry basis), indicative of a highly fermentable diet. Forage DM was determined twice weekly and as-fed mixing was adjusted accordingly to maintain DM proportions through time.

The sources of animal fat were Qual Fat (Darlington International Inc., Irving, TX) and CNO obtained from Akey Inc. (Lewisburg, OH). Fatty acid profiles of AFB and $\mathrm{CNO}$ and experimental diets are in Table 2. Fatty acids in both fat sources were in form of triglycerides. The FA profile of the dietary AFB in the current experiment (Table 2) was intermediate to the profiles of tallow $\left(25 \% \mathrm{C}_{16: 0}, 20 \% \mathrm{C}_{18: 0}, 43 \% \mathrm{C}_{18: 1}\right.$, and $\left.3 \% \mathrm{C}_{18: 2}\right)$ and choice white grease $\left(24 \% \mathrm{C}_{16: 0}, 11 \% \mathrm{C}_{18: 0}, 48 \%\right.$ $\mathrm{C}_{18: 1}$, and $12 \% \mathrm{C}_{18: 2}$ ) in a previous study (Onetti et al., 2001). Comparison of dietary tallow to choice white grease revealed no major differences in lactational per- 
Table 1. Ingredient and chemical compositions of experimental diets (experiments 1 and 2)

\begin{tabular}{|c|c|c|c|c|c|c|c|}
\hline \multirow{2}{*}{$\begin{array}{l}\text { Composition, } \\
\% \text { of DM (unless noted otherwise) }\end{array}$} & \multicolumn{7}{|c|}{ Treatment diet ${ }^{1}$} \\
\hline & CTRL & $5 \%-\mathrm{AFB}$ & $5 \%$-AFB-CNO & $5 \%-\mathrm{CNO}$ & $2 \%-\mathrm{CNO}$ & $3 \%-\mathrm{CNO}$ & $4 \%$-CNO \\
\hline \multicolumn{8}{|l|}{ Ingredient } \\
\hline Corn silage ${ }^{2}$ & 28.5 & 28.5 & 28.5 & 28.5 & 28.5 & 28.5 & 28.5 \\
\hline Alfalfa silage $^{3}$ & 7.4 & 7.4 & 7.4 & 7.4 & 7.4 & 7.4 & 7.4 \\
\hline Dried, shredded beet pulp & 8.4 & 8.4 & 8.4 & 8.4 & 8.4 & 8.4 & 8.4 \\
\hline Animal fat blend & - & 5.0 & 2.5 & - & - & - & - \\
\hline Coconut oil & - & - & 2.5 & 5.0 & 2.0 & 3.0 & 4.0 \\
\hline Corn gluten meal & - & 0.8 & 0.8 & 0.8 & 0.3 & 0.5 & 0.6 \\
\hline Urea & 0.7 & 0.7 & 0.7 & 0.7 & 0.7 & 0.7 & 0.7 \\
\hline Mineral-vitamin $\operatorname{mix}^{6}$ & 2.3 & 2.3 & 2.3 & 2.3 & 2.3 & 2.3 & 2.3 \\
\hline$\%$ from forage & 65.6 & 66.7 & 68.0 & 62.9 & 64.5 & 64.0 & 63.4 \\
\hline Starch & 34.8 & 28.9 & 30.1 & 30.1 & 32.9 & 31.9 & 31.0 \\
\hline Ether extract & 5.7 & 11.0 & 10.4 & 9.6 & 7.3 & 8.0 & 8.8 \\
\hline $\mathrm{CP}$ & 17.2 & 17.2 & 16.7 & 16.3 & 16.8 & 16.7 & 16.5 \\
\hline Rumen-undegradable $^{9}$ & 6.4 & 6.4 & 6.4 & 6.4 & 6.4 & 6.4 & 6.4 \\
\hline Total digestible nutrients & 70.7 & 69.8 & 69.8 & 68.4 & 73.3 & 73.2 & 73.0 \\
\hline Gross energy, Mcal $/ \mathrm{kg}$ & 4.13 & 4.45 & 4.38 & 4.32 & 4.21 & 4.24 & 4.28 \\
\hline
\end{tabular}

${ }^{1}$ Treatments were in experiment $1: \mathrm{CTRL}=$ control; $5 \%$-AFB $=$ animal fat blend; $5 \%$-CNO = coconut oil; $5 \%$-AFB-CNO = a $1: 1$ mixture of $\mathrm{AFB}$ and $\mathrm{CNO}$; and in experiment 2: 2,3 , or $4 \% \mathrm{CNO}$.

${ }^{2}$ Corn silage contained $31.5 \%$ DM (as fed), and 95.4\% OM, 45.1\% NDF, $10.8 \%$ indigestible NDF, 20.5\% starch, $8.3 \%$ ether extract (EE), and $8.7 \% \mathrm{CP}$, dry basis.

${ }^{3}$ Alfalfa haylage contained $28.5 \%$ DM (as fed), and $88.8 \%$ OM, 36.3\% NDF, $21.1 \%$ indigestible NDF, $0.4 \%$ starch, $10.3 \%$ EE, and $26.1 \%$ CP, dry basis.

${ }^{4}$ Alfalfa hay contained $90.1 \% \mathrm{DM}$ (as fed), and $88.7 \% \mathrm{OM}, 31.9 \% \mathrm{NDF}, 9.4 \%$ indigestible NDF, $4.7 \%$ starch, $3.6 \% \mathrm{EE}$, and $23.0 \%$ CP, dry basis. ${ }^{5}$ SoyPLUS (West Central Cooperative, Ralston, IA).

${ }^{6}$ Mineral-vitamin mix contained $38.1 \%$ limestone, $31.7 \%$ sodium bicarbonate, $13.1 \%$ dicalcium phosphate, $9.7 \%$ magnesium sulfate, $7.5 \%$ sodium chloride, $2.6 \%$ biotin $(1.4 \mathrm{~g} / \mathrm{kg}$ ), $1.9 \%$ trace minerals (contained $11.6 \% \mathrm{Ca}, 9.1 \% \mathrm{P}, 5.0 \% \mathrm{Fe}, 4.0 \% \mathrm{Mn}, 4.0 \% \mathrm{Zn}, 1.0 \% \mathrm{Cu}, 600 \mathrm{mg}$ of I/kg, 300 $\mathrm{mg}$ of Se $/ \mathrm{kg}$, and $200 \mathrm{mg}$ of $\mathrm{Co} / \mathrm{kg}$ ), 1.1\% Se-yeast, $57 \mathrm{KIU}$ of vitamin A/kg, $17 \mathrm{KIU}$ of vitamin D $/ \mathrm{kg}, 0.8 \mathrm{KIU}$ of vitamin E/ $/ \mathrm{kg}$, dry basis.

${ }^{7}$ The mineral composition of diets was $0.73 \% \mathrm{Ca}, 0.34 \% \mathrm{P}, 0.23 \% \mathrm{Mg}, 1.02 \% \mathrm{~K}, 0.28 \% \mathrm{Na}, 0.16 \% \mathrm{~S}, 251 \mathrm{mg}$ of Fe/kg, $45 \mathrm{mg}$ of Zn/kg, $13 \mathrm{mg}$ of $\mathrm{Cu} / \mathrm{kg}$, and $53 \mathrm{mg}$ of $\mathrm{Mn} / \mathrm{kg}$ (dry basis; analyzed by Dairy One Cooperative, Ithaca, NY).

${ }^{8}$ Based on 240-h in vitro fermentation of each individual dietary ingredient.

${ }^{9}$ Estimated using published values (NRC, 2001).

formance in dairy cows (Onetti et al., 2001). Based on FA composition, we presumed that the current AFB was comparable to dietary tallow in other experiments.

Experiment 2. Fifteen multiparous cows $[219 \pm 42$ DIM; $42.1 \pm 7.0-\mathrm{kg}$ milk yield (MY); mean $\pm \mathrm{SD}]$ were adjusted to a single diet (CTRL from experiment 1) for $15 \mathrm{~d}$. Cows were blocked according to DMI 2 d before introduction of treatments and assigned to 1 of 3 treatment diets. Treatment diets were similar to CTRL, except that 2, 3, or $4 \%$ CNO (2\%-CNO, 3\%CNO, and 4\%-CNO, respectively) and corn gluten meal replaced ground corn isonitrogenously (Table 1). Cows were fed treatment diets for $8 \mathrm{~d}$.

\section{Data and Sample Collections}

Management of cows was identical in both experiments. Cows were kept in tie-stalls, fed TMR once daily ad libitum, and milked twice daily. Individual cows' feed consumption and MY were recorded daily. Milk was sampled from 4 consecutive milkings during the preliminary period (d 4 and 3 before introduction of treatments), and on d 18 and 19 of the experiment. Milk samples for component analysis were stored at $4^{\circ} \mathrm{C}$ and analyzed within $1 \mathrm{~d}$. Milk samples for determinations of FA profile and citrate concentration were stored at $-20^{\circ} \mathrm{C}$. Chromic oxide served as an external 
Table 2. Fatty acid (FA) profile of fat sources and dietary treatments in experiment $1^{1}$

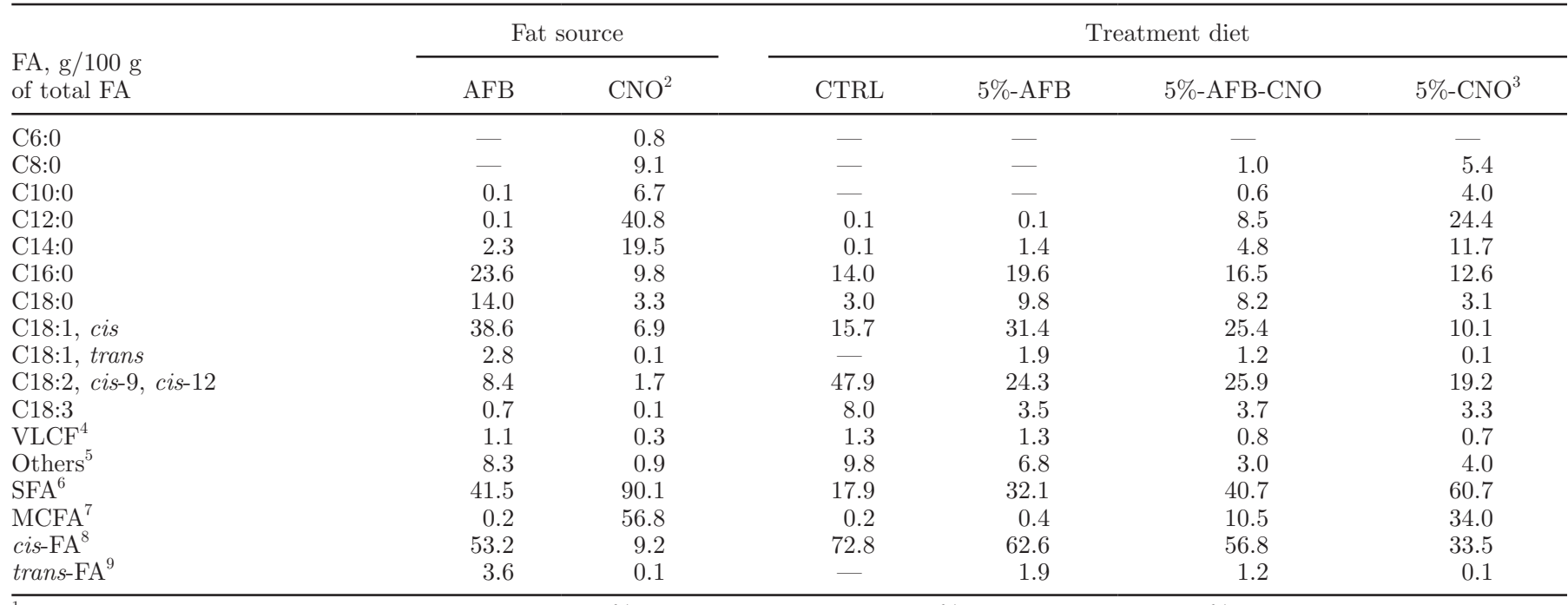

${ }^{1}$ Treatments were in experiment $1: \mathrm{CTRL}=$ control; $5 \%$-AFB $=$ animal fat blend; $5 \%$-CNO $=$ coconut oil; $5 \%$-AFB-CNO $=$ a $1: 1$ mixture of $\mathrm{AFB}$ and $\mathrm{CNO}$.

${ }^{2}$ The same source of $\mathrm{CNO}$ was used in experiment 2.

${ }^{3}$ Calculated concentrations of FA (not actually measured for this treatment diet).

${ }^{4} \mathrm{VLCF}=$ total very long-chain $\mathrm{FA}\left(\geq \mathrm{C}_{20}\right)$.

${ }^{5}$ Others $=$ FA not listed in table and FA not identified.

${ }^{6} \mathrm{SFA}=$ total saturated FA.

${ }^{7} \mathrm{MCFA}=$ total medium-chain $\mathrm{FA}\left(\mathrm{C}_{8} \leq \mathrm{MCFA}<\mathrm{C}_{14}\right)$.

${ }^{8}$ cis-FA $=$ total $\mathrm{FA}$ with a cis-configuration.

${ }^{9}$ trans-FA $=$ total FA with a trans-configuration.

marker to determine apparent total-tract digestibilities of nutrients, because digestibility of chromic oxide is minute (Crampton and Lloyd, 1951). Ground spelt hulls and $5 \mathrm{~g}$ of chromic oxide were combined and filled into a gelatin capsule (1.5 oz.; Torpac Inc., Fairfield, $\mathrm{NJ})$. Cows were dosed ruminally via the esophagus every $8 \mathrm{~h}$ from d 14 through $21\left(15 \mathrm{~g}\right.$ of $\left.\mathrm{Cr}_{2} \mathrm{O}_{3} / \mathrm{d}\right)$ with a priming dose of $45 \mathrm{~g}$ on $\mathrm{d} 14$. Fecal samples were collected per rectum every $9 \mathrm{~h}$ from d 19 through 21 . Thus, 8 fecal samples per cow were obtained, covering every 3 -h interval of a 24 -h period. Additionally, individual forages and concentrate mixes were sampled every other day during wk 3 and composited to provide 1 sample per ingredient. Feed and fecal samples were frozen immediately and stored at $-20^{\circ} \mathrm{C}$.

\section{Sample and Data Analyses}

Laboratory Analyses. All individual forage and concentrate samples and all fecal samples were subsampled and lyophilized (TriPhilizer MP; FTS Systems Inc., Stone Ridge, NY). Forage and fecal samples were ground using a Wiley mill (1-mm screen; Arthur H. Thomas Co., Philadelphia, PA). Feed concentrate samples were ground with a cyclone mill (Cyclotec
1093; Foss, Eden Prairie, MN). Fecal samples were composited by cow based on DM content after drying to constant weight at $105^{\circ} \mathrm{C}$ in a forced-air oven. Feed and fecal samples were analyzed for ash concentration by 5 -h oxidation at $500^{\circ} \mathrm{C}$ in a muffle furnace. Organic matter content was the difference between DM and ash content. Concentrations of $\mathrm{CP}$ and NDF were determined according to Hach et al. (1987) and Van Soest et al. (1991; method A), respectively. To obtain starch concentration, samples were gelatinized with $\mathrm{NaOH}$, and then glucose concentration was measured enzymatically (Karkalas, 1985; Glucose kit \#510; Sigma Chemical Co., St. Louis, MO) using a microplate absorbance reader (SpectraMax 190; Molecular Devices Corp., Sunnyvale, CA). Indigestible NDF was determined as NDF residue after 240-h in vitro fermentation (Goering and Van Soest, 1970). Ruminal fluid used in the fermentation was obtained from 2 nonpregnant, nonlactating cows fed solely grass hay. Potentially digestible NDF (pdNDF) was calculated as the difference between NDF and indigestible NDF. Ether extract (EE) was analyzed according to the AOAC (1990) method. For analysis of $\mathrm{Cr}$, samples were digested with phosphoric acid (Williams et al., 1962), and Cr was detected by flame atomic absorption spectrometry (SpectraAA 220; 
Varian Inc., Victoria, Australia). Gross energy (GE) was derived from bomb calorimetry (model 1241; Parr Instrument Inc., Moline, IL). Metabolizable energy and $\mathrm{NE}_{\mathrm{L}}$ for intake were calculated according to NRC (2001), based on digestible energy (DE) measured in the experiment and milk production level using the following equations:

$$
\begin{gathered}
\mathrm{ME}_{(\text {intake) }}=\left(1.01 \times \mathrm{DE}_{(\text {intake })}-0.45\right) \\
+0.0046 \times([\mathrm{EE}]-3) ; \\
\mathrm{NE}_{\mathrm{L}(\text { intake) }}=0.703 \times \mathrm{ME}_{(\text {intake) }}-0.19 \\
+\left(0.097 \times \mathrm{ME}_{(\text {intake) }}+0.19\right) / 97 \times([\mathrm{EE}]-3) .
\end{gathered}
$$

Fatty acids were extracted from individual forage and concentrate samples and from pooled fecal samples (Sukhija and Palmquist, 1988) and determined by gas chromatography (model 8500; Perkin-Elmer Corp., Norwalk, CT) with the following specifications: SP2560 capillary column $(100 \mathrm{~m} \times 0.20 \mathrm{~mm}$ i.d. with 0.02- $\mu \mathrm{m}$ film thickness; Supelco, Bellefonte, PA); oven temperature at $70^{\circ} \mathrm{C}$ for $4 \mathrm{~min}$, then increased by $13^{\circ} \mathrm{C} /$ min to $175^{\circ} \mathrm{C}$ and sustained for 27 min before being increased again at $4^{\circ} \mathrm{C} / \mathrm{min}$ to $215^{\circ} \mathrm{C}$ and sustained for 31 min; and $\mathrm{H}$ flow of $20 \mathrm{~cm} / \mathrm{s}$ at the Nutrition Laboratory of the Michigan State University Diagnostic Center for Population Animal Health (East Lansing).

Milk samples were assayed for fat, true protein, SNF, lactose, and MUN by mid-infrared spectroscopy (AOAC, 1990) by Michigan DHI (East Lansing). Solids-corrected MY (SCMY) was calculated according to Tyrrell and Reid (1965) with conversion of milk true protein to milk CP by a factor of 0.95 (Verdi et al., 1987) using the following equation:

$$
\begin{aligned}
& \mathrm{SCMY}=\{\mathrm{MY} \times([\text { milk fat }] \times 41.63 \\
& +[\text { milk true protein }] / 0.95 \times 24.13 \\
& +[\text { milk lactose }] \times 21.6)-11.72\} / 340
\end{aligned}
$$

Milk $\mathrm{NE}_{\mathrm{L}}$ was calculated as

$$
\begin{aligned}
& \mathrm{NE}_{\mathrm{L}(\text { milk })}(\mathrm{Mcal} / \mathrm{d})=\mathrm{MY}(\mathrm{kg}) \times(0.0929 \\
& \times[\text { milk fat }]+0.0563 \times[\text { milk true protein }] \\
& \quad+0.0395 \times[\text { milk lactose }]) .
\end{aligned}
$$

Milk samples and samples of $\mathrm{AFB}$ and $\mathrm{CNO}$ were prepared for determination of FA profile as described by Bradford and Allen (2004) and assayed as described above. Milk samples were defatted and deproteinized according to Garnsworthy et al. (2006), and milk citrate concentration was measured enzymatically (Mollering, 1989; Kit K-CITR; Megazyme International Ireland Ltd., Bray, Ireland) and read with a DU 7400 spectrophotometer (Beckman Coulter Inc., Palo Alto, CA).

\section{Statistical Analysis}

All analyses were conducted with SAS (version 9.1.3; SAS Institute Inc., Cary, NC) with block defined as random variable in a randomized complete block design. In all statistical analyses, residual distributions were assessed for normality using the Shapiro-Wilk test and data were transformed, when test statistic was less than 0.05. This was the case for $\mathrm{C}_{18: 2}$ trans-10,cis-12 . Back-transformed least squares means are reported. Additionally, transformed, pooled standard errors of the means and back-transformed $95 \%$ confidence intervals are provided in the respective table. Distribution of Cook's $D$ statistic was inspected visually and outliers were removed from the analysis. No more than 1 datum was removed from any analysis. Significance of treatment effects was declared at $P<0.05$, and tendencies were declared at $P<0.10$ for main effects and $P<0.15$ for interactions. One cow in the AFB treatment was removed part way through experiment 1 due to injury not related to the experiment and its data for d 15 to 21 of the experiment were excluded from all analyses.

Experiment 1. Data were averaged across d 15 through 21 of the experiment and analyzed by leastsquares ANOVA using the MIXED procedure (SAS, version 9.1.3; SAS Institute Inc., Cary, NC) with the fixed effect of treatment as the independent variable. Pre-experimental data were used as a covariate in the model if they interacted with treatment $(P<0.15)$. The magnitude of the covariance variable at which treatments differed $(P<0.05)$ was determined by mathematical approximation (breakpoint analysis) using the AT option in SAS. Statistical differences in daily DMI of CTRL versus 5\%-CNO, and 5\%-AFB and $5 \%$-AFB-CNO versus $5 \%$-CNO at the start of experiment 1 were determined by paired, 2-tailed Student's $t$-test, because DMI in 5\%-CNO-fed cows decreased severely and the treatment was discontinued. Treatment effects during wk 3 of the experiment were separated using orthogonal contrasts 1) of addition of fat (CTRL vs. $5 \%$-AFB and $5 \%$-AFB-CNO) and 2) source of fat (5\%-AFB vs. $5 \%$-AFB-CNO). The CORR procedure was used to determine correlations between dependent variables and significance was declared at $P<0.05$.

Experiment 2. Dry matter intake data were analyzed using the fixed effects of treatment and day of experiment and their interaction with the MIXED procedure of SAS. Day was the repeated measure subject- 
ed to cow within treatment. The variance-covariance structure chosen was autoregressive (1) based on the lowest Bayesian value. Dry matter intake from the week before the treatment period was fitted as the covariate. The SLICE option was used to detect differences within each treatment across all days of the experiment or within each day of the experiment across all treatments, because the interaction of treatment and day of the experiment tended to be significant $(0.05<P<$ $0.15)$. Orthogonal contrasts were used to test for linear and quadratic responses in DMI across days within individual treatment and across diet within individual days.

\section{RESULTS}

Dietary treatments containing $\mathrm{CNO}$ in experiment 1 (5\%-AFB-CNO and 5\%-CNO) were slightly lower than expected for EE concentration and GE density compared with 5\%-AFB (Table 1). For example, dietary EE concentration was $9.6 \%$ for $5 \%$-CNO, but we expected $10.7 \%$ based on the EE concentration for CTRL (Table 1). Thus, approximately 1 percentage unit (20\%) of fat added to 5\%-CNO was not accounted for in the EE concentration. Furthermore, the concurrent analyzed vs. calculated proportions of $\mathrm{C}_{8: 0}(1.0$ vs. $2.7 \%), \mathrm{C}_{10: 0}(0.6$ vs. $2.0 \%), \mathrm{C}_{12: 0}$ (8.5 vs. $12.2 \%$ ), and $\mathrm{C}_{14: 0}(4.8$ vs. $5.9 \%)$ were lower than expected for 5\%-AFB-CNO (Table 2). This was counterbalanced with a greater than expected proportion of dietary LCFA in 5\%-AFB-CNO. In contrast to $5 \%$-AFB-CNO, the FA profile for the $5 \%$-CNO diet in Table 2 was calculated retrospectively based on FA profiles for $\mathrm{CNO}, \mathrm{AFB}$, and 5\%-AFB.

\section{DMI Responses}

Short-Term Response (d 1 to 5 or 8 ). The DMI during the pre-experimental and experimental periods are shown in Figure 1A for experiment 1 and Figure $1 \mathrm{~B}$ for experiment 2 . In experiment 1 , the dietary $5 \%$ CNO treatment decreased DMI precipitously on $\mathrm{d} 1$ compared with CTRL, and DMI remained depressed through d 5 ( $\left.P_{t \text {-test }}<0.05\right)$. Also, 5\%-CNO-fed cows consumed less DM on d 1 through 5 compared with cows fed $5 \%$-AFB or $5 \%$-AFB-CNO $\left(P_{t \text {-test }}<0.01\right)$, although $5 \%$-AFB, $5 \%$-AFB-CNO, and 5\%-CNO treatment diets contained similar amounts of added fat. As a result of lower DMI, cows fed 5\%-CNO consumed appreciably less energy than cows fed 5\%-AFB or 5\%-AFB-CNO in the initial 5-d period of the experiment. Therefore, the 5\%-CNO treatment was discontinued after d 5 and cows were switched back to CTRL. After the switch back to CTRL, cows previously fed 5\%-CNO increased their DMI by $23 \%$ within $1 \mathrm{~d}$. Nonetheless, a carryover effect of dietary CNO occurred, because the DMI of cows previously fed $5 \%$-CNO remained about $10 \%$ less than that of cows fed CTRL on d 6 through 10 (Figure $1 \mathrm{~A})$.

In experiment 2 , the concentration of dietary $\mathrm{CNO}$ tended to interact with day of the experiment $\left(P_{\text {interaction }}\right.$ $<0.10$; Figure 1B). The interaction was defined (based
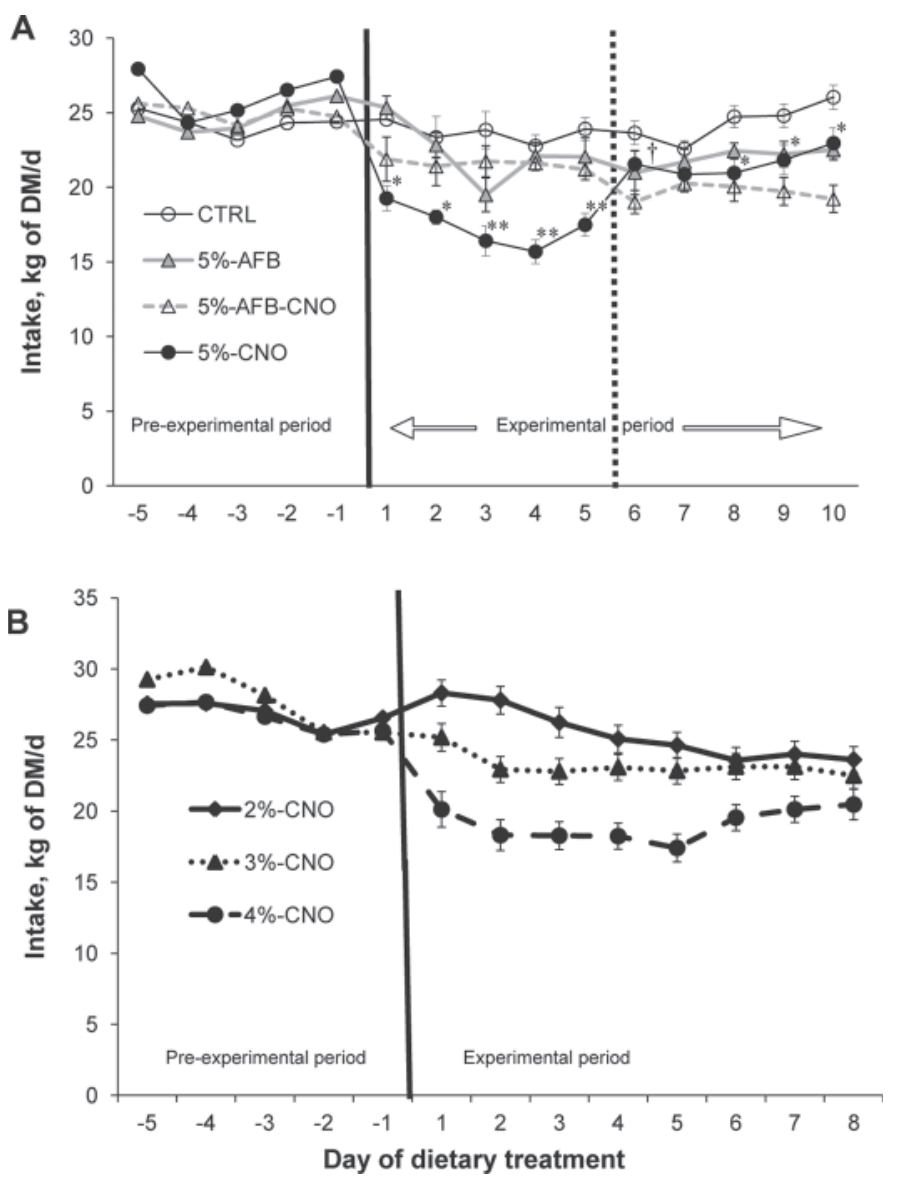

Figure 1. Dry matter intake responses to dietary treatments containing coconut oil (CNO), animal fat blend (AFB), or a 1-to-1 mixture of $\mathrm{AFB}$ and $\mathrm{CNO}$ in experiment 1 (A); or, 2, 3, or $4 \% \mathrm{CNO}$ in experiment 2 (B). A: All cows were offered the control diet (CTRL) during the pre-experimental period. Treatments were 5\%-AFB; $5 \%$-AFB-CNO, or 5\%-CNO. Cows receiving 5\%-CNO were switched to CTRL after d 5. Differences $(* *=P<0.01 ; *=P<0.05$; $\dagger=$ $P<0.10)$ between CTRL and 5\%-CNO were determined by paired, 2 -tailed Student's $t$-test; $\mathrm{n}=8$ cows per treatment. Error bars are standard errors of the means. Solid vertical line indicates initiation of dietary treatments. Dotted vertical line indicates discontinuation of 5\%-CNO treatment after d 5. B: All cows were offered CTRL during the 5-d pre-experimental period, and 2, 3, or $4 \%$ dietary CNO during the 8 -d experimental period. $\mathrm{n}=5$ cows per dietary treatment. Error bars are standard errors of the means. A tendency was observed for an interaction of dietary treatment by day of experiment $(P<0.10)$. Effect of dietary treatment was significant $(P<0.01)$ for each day of experimental period with the exception of d $8(P<0.10)$. Daily DMI varied across days of experiment with $2 \%$-CNO $(P<0.001)$ and $3 \%$ CNO $(P<0.08)$, but not for $4 \%-\mathrm{CNO}$ treatment $\operatorname{diet}(P>0.5)$. Solid vertical line indicates initiation of treatments. 
Table 3. Effects of dietary fat treatments on intakes and apparent total-tract digestibilities of dietary components and nutrients (experiment 1 )

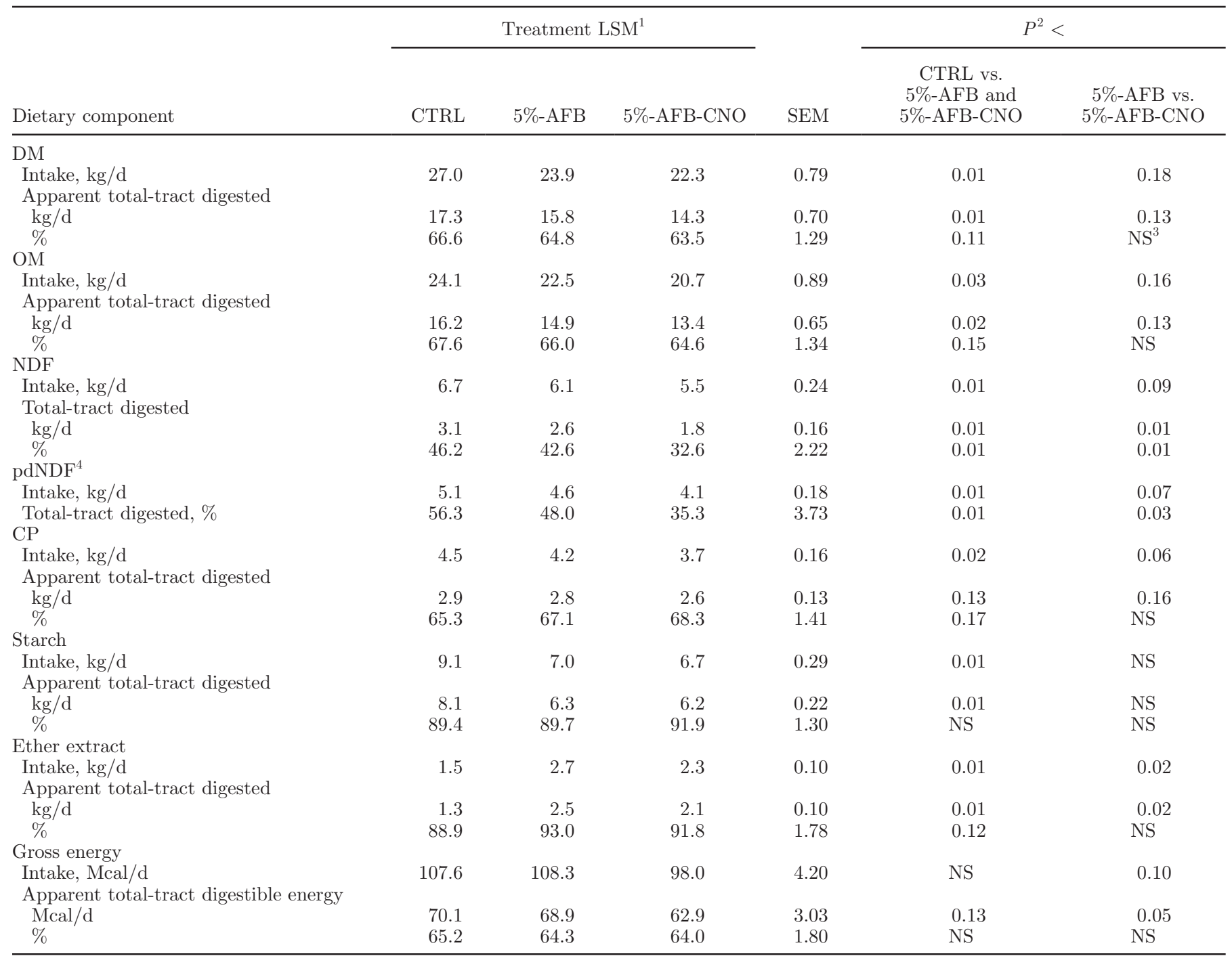

${ }^{1}$ Treatments were CTRL $=$ control; $5 \%$-AFB $=$ animal fat blend; $5 \%$-AFB-CNO = a 1:1 mixture of AFB and coconut oil.

${ }^{2}$ Orthogonal contrasts for dietary fat and for source of dietary fat (chain length of fatty acids).

${ }^{3} \mathrm{NS}=$ nonsignificant $(P>0.20)$.

${ }^{4} \mathrm{pdNDF}=$ potentially digestible NDF (the difference of dietary NDF and indigestible NDF). Indigestible NDF was determined via 240-h in vitro fermentation of individual dietary ingredients.

on the SLICE option in SAS) because DMI of cows fed $2 \%$-CNO decreased during the 8 -d experimental period $(P<0.01)$ following an increase in DMI on $\mathrm{d}$ 1. Furthermore, cows fed $3 \%$-CNO tended to decrease their DMI during the 8 -d period $(P<0.08)$. However, DMI did not differ for cows fed $4 \%$-CNO across the experimental period $(P>0.5)$. This suggests that the observed response in DMI occurred on $\mathrm{d} 1$ in cows fed $4 \%$-CNO and thereafter, DMI remained relatively steady across the following $7 \mathrm{~d}$. Feeding cows a dietary CNO concentration of 2,3 , and $4 \%$, dry basis, decreased DMI from 25.3 to 23.1 and $19.1 \mathrm{~kg} / \mathrm{d}$ (SEM = $0.62 ; P<0.05)$, respectively, pooled across days of the experiment. This response to $\mathrm{CNO}$ concentration was quadratic $(P<0.02)$.

Mid-Term Response (d 15 to 21). In experiment 1 , dietary fat sources (5\%-AFB and $5 \%$-AFB-CNO vs. CTRL) decreased DMI on average $3.9 \mathrm{~kg} /$ cow per day in wk $3(P<0.01$; Table 3$)$. However, DMI did not differ between 5\%-AFB and 5\%-AFB-CNO-fed cows.

\section{Nutrient Digestibility}

Dietary fat treatments decreased intakes of OM, NDF, pdNDF, and CP, as would be expected with decreased DMI compared with CTRL (Table 3). Intake of starch 
Table 4. Effects of dietary fat treatments on lactational performance (experiment 1)

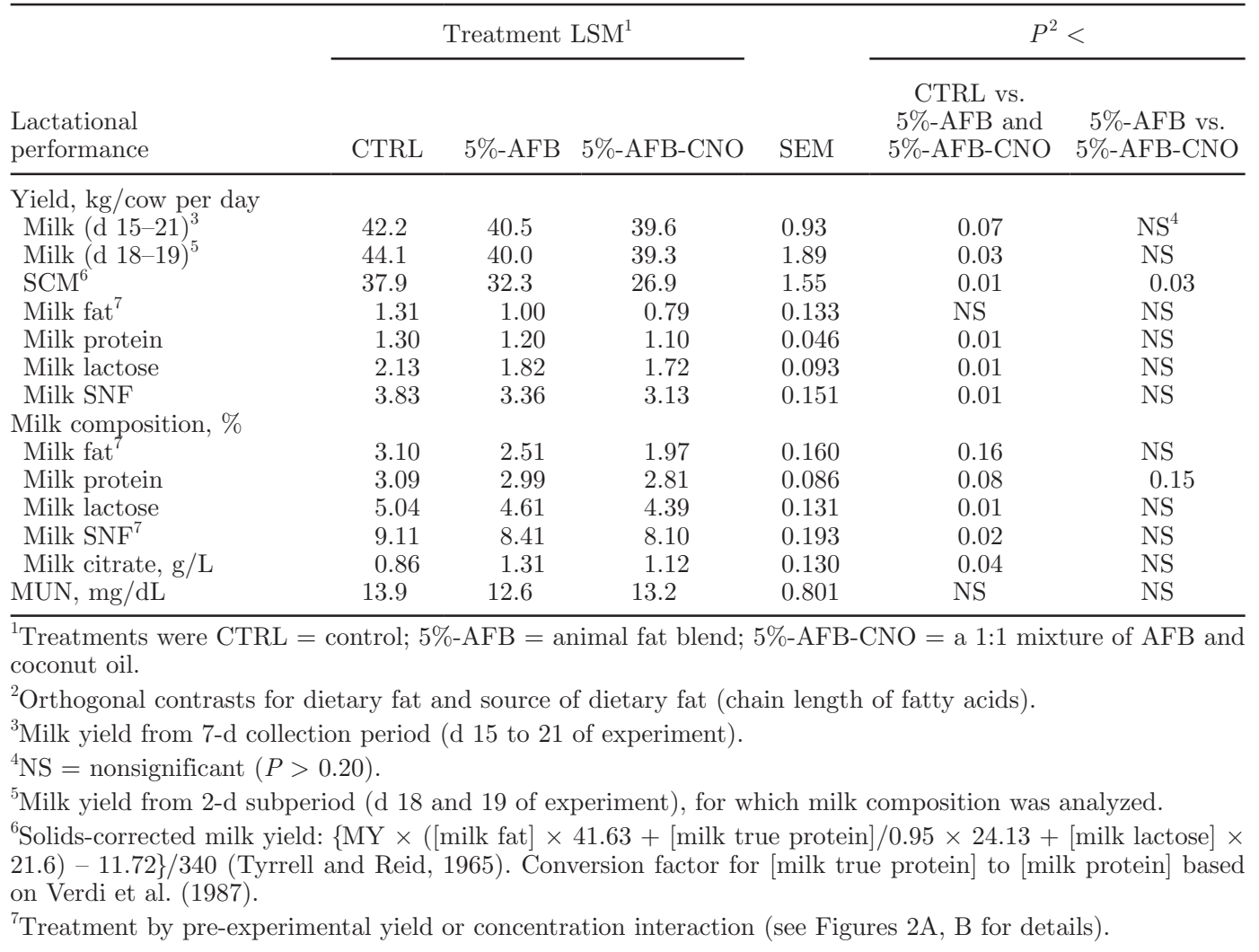

was less, and intake of EE increased with dietary fat treatments because added fats replaced portions of corn grain in the diet. Fat treatments resulted in lower amounts of apparently digested DM, OM, and NDF $(P$ $<0.02)$, but not $\mathrm{CP}(P>0.10$; Table 3$)$. As expected, the amount of apparently digested EE was greater and the amount of apparently digested starch was less for cows fed fat treatments compared with CTRL. Dietary fat treatments resulted in decreased coefficients for totaltract digestibility of NDF and pdNDF (Table $3 ; P<$ 0.01) compared with CTRL. However, apparent digestion coefficients for DM, OM, CP, starch, EE, and GE did not differ due to treatments. Cows fed 5\%-AFB consumed more EE and DE than cows fed 5\%-AFB-CNO. Furthermore, NDF, pdNDF, and CP intake tended to be lower for cows fed 5\%-AFB-CNO compared with those fed 5\%-AFB (Table 3). Cows fed 5\%-AFB-CNO apparently digested less NDF and EE compared with cows fed $5 \%$-AFB $(P<0.02$; Table 3$)$. Moreover, $5 \%$-AFB-CNO resulted in lower total-tract digestion coefficients for NDF and pdNDF (Table $3 ; P<0.03$ ).

\section{Milk Production and Composition}

Overall, dietary fat sources (5\%-AFB and 5\%-AFB$\mathrm{CNO}$ vs. CTRL) decreased yields of SCM, protein, lactose, and $\mathrm{SNF}(P<0.01 ;$ Table 4$)$ and tended to decrease MY $(P<0.07)$. The decrease in SCMY was exacerbated in $5 \%$-AFB-CNO compared with $5 \%$-AFB $(P<0.03)$.

Milk fat concentration was low $(3.10 \%)$ for CTRL (Table 4), as expected with the highly fermentable, highstarch diet. Milk fat concentration was even lower for cows fed 5\%-AFB (2.51\%) and 5\%-AFB-CNO (1.97\%). We tested the possibility that pre-experimental milk fat concentrations (covariate) affected the magnitude of milk fat concentration response (milk fat concentration on d 18 and 19 of the experiment minus milk fat concentration during the pre-experimental period). Overall, a tendency was observed for an interaction of dietary treatment and milk fat concentration response to dietary fat treatment $\left(P_{\text {interaction }}<0.10\right.$; Figure $\left.2 \mathrm{~A}\right)$. Dietary treatment did not affect milk fat concentration response when pre-experimental milk fat concentrations were below $2.6 \%$. However, both dietary fat treatments reduced milk fat concentration $(P<0.05)$ as preexperimental milk fat concentration was greater than $2.6 \%$. Cows fed $5 \%$-AFB or $5 \%$-AFB-CNO had lower concentrations of milk lactose and SNF $(P<0.02)$, but greater milk citrate concentrations $(P<0.04$; Table 4$)$ than cows fed CTRL. Furthermore, dietary fat treatment tended to lower milk protein concentration $(P$ 

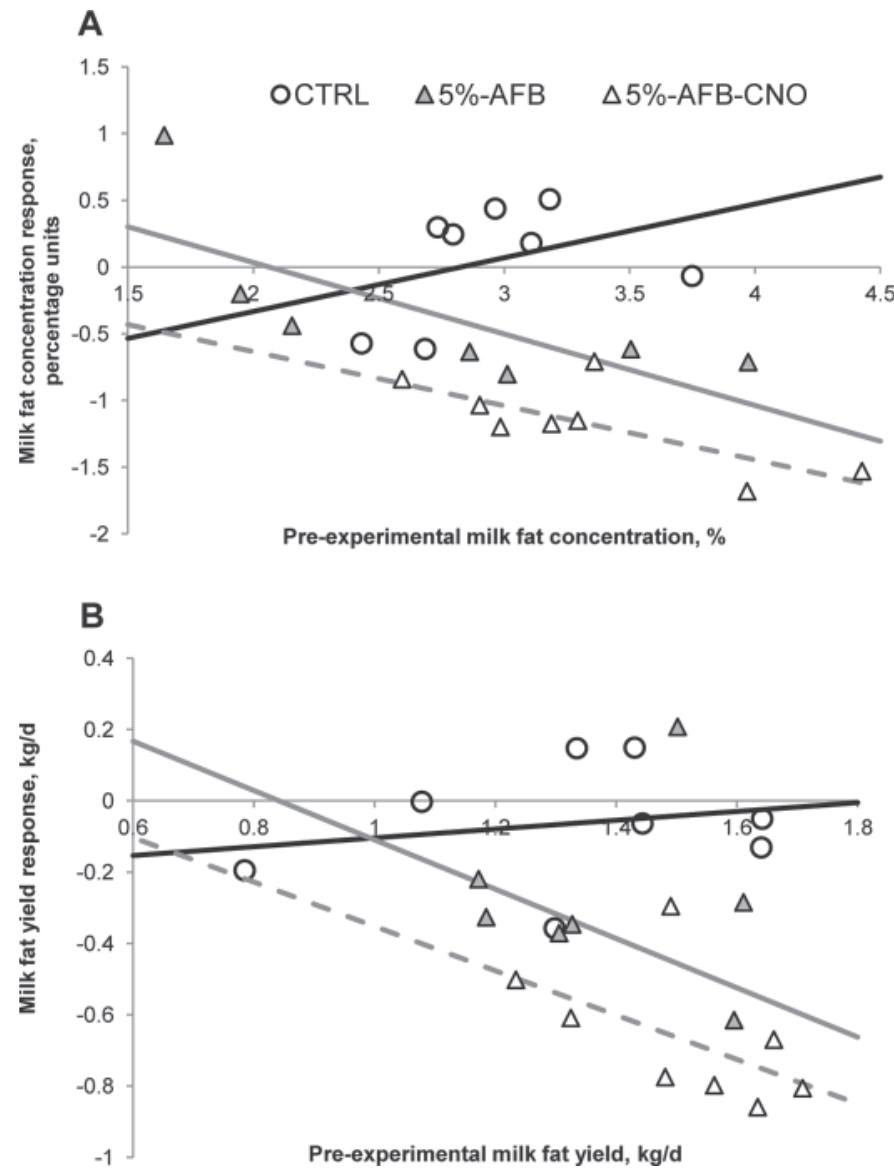

Figure 2. Effect of pre-experimental milk fat concentration (A) and yield (B) on milk fat concentration and yield responses to dietary fat treatments (experiment 1). Treatments were control (CTRL), animal fat blend (5\%-AFB), or a 1:1 mixture of AFB and coconut oil (5\%-AFB-CNO). Response was calculated as the difference of preexperimental milk fat concentration or yield and experimental milk fat concentration or yield. Trend lines refer to CTRL (solid black line), 5\%-AFB (solid gray line), and 5\%-AFB-CNO (dashed gray line). Equations for resulting trend lines were in (A) CTRL: $y=$ $0.40( \pm 0.410) \times \mathrm{x}-1.14( \pm 1.222), 5 \%$-AFB: $\mathrm{y}=-0.54( \pm 0.220) \times$ $\mathrm{x}+1.10( \pm 0.625), 5 \%$-AFB-CNO: $\mathrm{y}=-0.41( \pm 0.148) \times \mathrm{x}-0.18$ $( \pm 0.501)$; and in (B) CTRL: $\mathrm{y}=0.12( \pm 0.236) \times \mathrm{x}-0.23( \pm 0.321)$, $5 \%$-AFB: $\mathrm{y}=-0.69( \pm 0.357) \times \mathrm{x}+0.58( \pm 0.454), 5 \%$-AFB-CNO: y $=-0.62( \pm 0.394) \times \mathrm{x}+0.27( \pm 0.599)$.

$<0.08)$. Milk component concentrations did not differ between 5\%-AFB and 5\%-AFB-CNO.

Dietary treatments did not affect milk fat yield overall; however, milk fat yield of the pre-experimental (covariate) period tended to relate to the milk fat yield response (milk fat yield on d 18 and 19 of the experiment minus milk fat yield during the pre-experimental period; $P_{\text {interaction }}<0.12$; Figure $2 \mathrm{~B}$ ). Fat treatments did not affect milk fat yield response $(P>0.05)$ for low fat-yielding cows in the pre-experimental period. The response in fat yield in 5\%-AFB or 5\%-AFB-CNO-fed cows was decreased $(P<0.05)$ when pre-experimental (covariate) milk fat yield was greater than $1.16 \mathrm{~kg} / \mathrm{cow}$ per day. Milk fat yield response did not differ from 0 in CTRL-fed cows $(P>0.20)$. Dietary inclusion of fats decreased yields of milk protein, lactose, and SNF $(P<$ 0.01; Table 4); however, yields were similar for cows fed $5 \%$-AFB or $5 \%$-AFB-CNO.

The AFB and 5\%-AFB-CNO diets versus CTRL resulted in lower concentrations of milk FA shorter than $\mathrm{C}_{12}$ (presumably from de novo synthesis; Table 5). However, substitution of 2.5 percentage units of dietary $\mathrm{AFB}$ with $\mathrm{CNO}$ increased concentrations of $\mathrm{C}_{12}$ and $\mathrm{C}_{14}$ in milk compared with 5\%-AFB. Both dietary fat treatments increased concentrations of trans-unsaturated FA and $\mathrm{C}_{18: 2}$ trans-10,cis-12 (Table 5; $P<0.03$ ). Concentrations of $\mathrm{C}_{18: 2}$ trans-10,cis-12 related linearly to respective milk fat concentrations for the pre-experimental $(\mathrm{r}=-0.66 ; P$ $<0.001)$ and experimental period $(\mathrm{r}=-0.69 ; P<$ 0.001). Concentrations of $\mathrm{C}_{18: 2}$ trans -10 ,cis-12 were similar in milk fat from cows fed 5\%-AFB or 5\%-AFB-CNO. The activity of $\Delta^{9}$-desaturase in the mammary gland was greater for cows fed fat treatments than in CTRL based on desaturase ratios (Table 5).

Yields of milk FA shorter than $\mathrm{C}_{12}, \mathrm{C}_{12}$ to $\mathrm{C}_{14}$, and longer than $\mathrm{C}_{16}$ were greater for cows fed CTRL than those fed fat treatments (Figure 3). Yield of $\mathrm{C}_{16}$ milk FA depended on the respective $\mathrm{C}_{16}$ yield during the pre-experimental period $\left(P_{\text {interaction }}<0.05\right)$ of cows fed CTRL; however, yield of $\mathrm{C}_{16}$ milk FA in cows fed fat treatments did not relate to the pre-experimental yield. The interaction of treatment diet with pre-experimental yield of $\mathrm{C}_{16}$ was comparable to interactions of treatment diet and pre-experimental milk fat concentration and yield (Figures 2A and B). Yields of milk FA longer than $\mathrm{C}_{16}$ were lower for cows fed 5\%-AFB-CNO than $5 \%$-AFB (Figure 3).

\section{Energy and Protein Efficiency}

Table 6 shows the conversion of DE intake to milk $\mathrm{NE}_{\mathrm{L}}$. Specifically, cows fed 5\%-AFB-CNO consumed less $\mathrm{NE}_{\mathrm{L}}(P<0.05)$ than those fed 5\%-AFB. Moreover, $\mathrm{NE}_{\mathrm{L}}$ intake was intermediate for cows fed 5\%-AFB compared with those fed CTRL and 5\%-AFB-CNO. Added dietary fats (5\%-AFB and 5\%-AFB-CNO vs. CTRL) decreased secretion of milk $\mathrm{NE}_{\mathrm{L}}(P<0.01)$ and tended to reduce efficiency of converting DE into milk $\mathrm{NE}_{\mathrm{L}}(P<0.10)$. The dietary 5\%-AFB-CNO treatment further exacerbated the decrease in milk $\mathrm{NE}_{\mathrm{L}}$ secretion $(P<0.03)$ compared with 5\%-AFB. However, the efficiency of converting $\mathrm{DE}$ into milk $\mathrm{NE}_{\mathrm{L}}$ did not differ. Conversion of dietary CP into milk protein was $29 \%$ (pooled SEM: 0.9) and did not differ by dietary treatment (results not shown; $P>0.5$ ). 
Table 5. Effects of dietary fat treatments on milk FA profile (experiment 1)

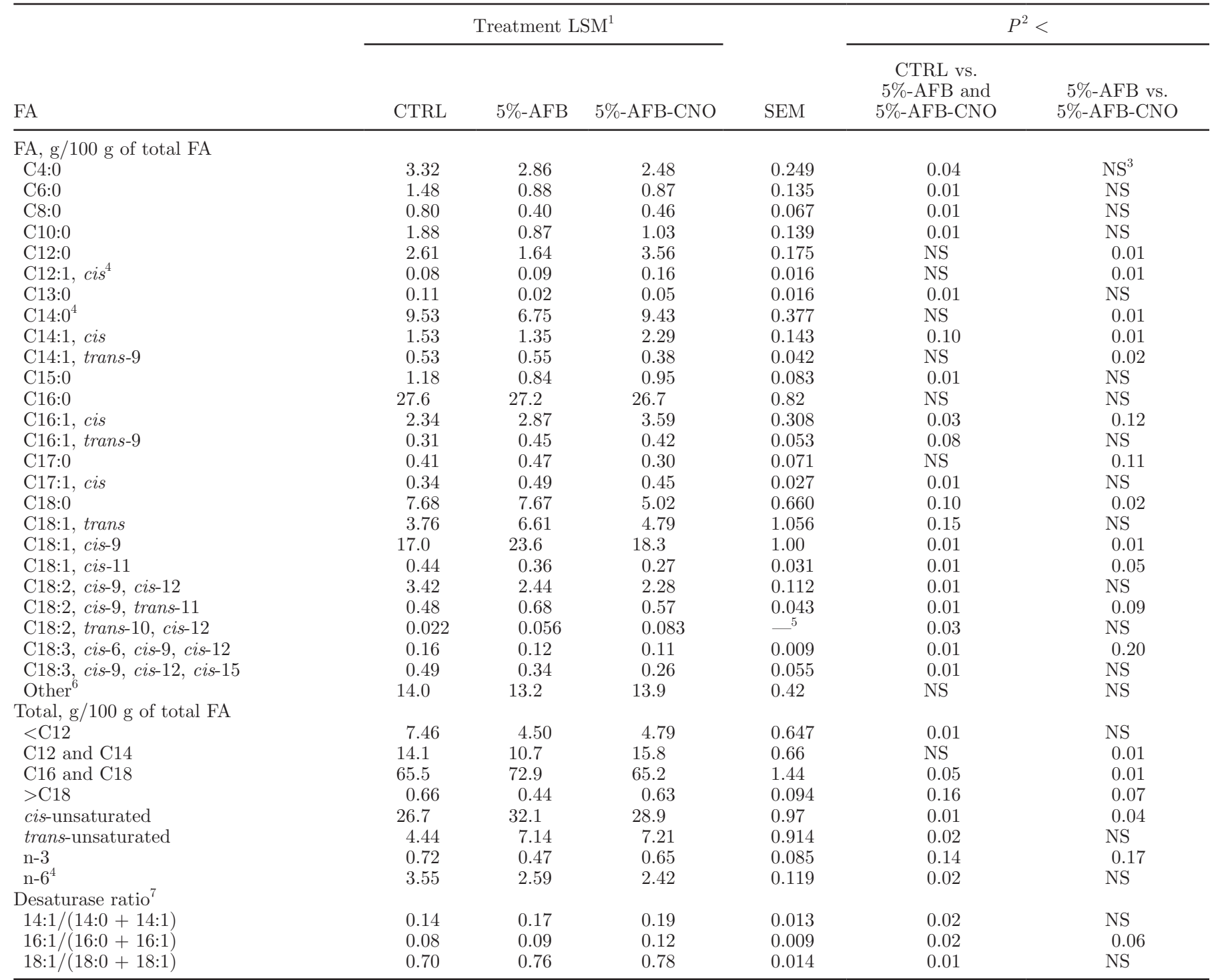

${ }^{1}$ Treatments were $\mathrm{CTRL}=$ control; $5 \%$-AFB $=$ animal fat blend; $5 \%$-AFB-CNO = a 1:1 mixture of AFB and coconut oil.

${ }^{2}$ Orthogonal contrasts for dietary fat and source of dietary fat (chain length of FA).

${ }^{3} \mathrm{NS}=$ nonsignificant $(P>0.20)$.

${ }^{4}$ Interaction of treatment by pre-experimental concentration of individual FA.

${ }^{5}$ Data were transformed for analysis $\left[\mathrm{X}_{\text {trans }}=\mathrm{LN}(\mathrm{X}+0.01)\right]$. Pooled standard errors of the means of transformed results: SEM $=0.301 . \mathrm{Least}$ squares means are back-transformed. $95 \%$ confidence intervals are CTRL: 0.006 to $0.051 \%$; 5\%-AFB: 0.026 to $0.111 \%$; $5 \%$-AFB-CNO: 0.040 to $0.161 \%$.

${ }^{6}$ Fatty acids not listed above.

${ }^{7}$ Ratio for FA pairs that represent product/(substrate + product) for $\Delta^{9}$-desaturase; double bonds are cis-9.

\section{DISCUSSION}

Two major effects were observed of dietary supplementation with saturated MCFA (via CNO) and, to a lesser degree, LCFA (via AFB) on lactational performance of lactating dairy cows fed a highly fermentable diet. First, the abrupt introduction of a large concentration of $\mathrm{CNO}$ and, to a lesser degree, the mixture of $\mathrm{AFB}$ and $\mathrm{CNO}$ depressed intakes of $\mathrm{DM}$ and energy ( $\mathrm{DE}$ and $\mathrm{NE}_{\mathrm{L}}$ ), and consequently, decreased SCMY. Dietary CNO can influence DMI based on increase in ruminal fill (Allen, 2000) due to decrease in NDFD, excessive oxidation of metabolic fuels (Allen et al., 2009), changes in plasma concentrations of gut peptides (Feltrin et al., 2004), or palatability or acceptability. Second, dietary fat treatments exacerbated MFD. Specifically, 5\%-AFB-CNO 
decreased the yields of all milk FA categories based on chain length compared with CTRL (Figure 3). Presumably, decreased ruminal NDFD caused the decrease in total-tract NDF digestion, and changes in ruminal biohydrogenation exacerbated MFD, changed milk FA de novo synthesis and profile, and decreased milk lactose concentration.

\section{DMI Regulation}

Dietary concentration of CNO greater than or equal to $4 \%$ markedly and quickly depressed DMI as much as $40 \%$ (Figures $1 \mathrm{~A}$ and $\mathrm{B}$ ) in a highly fermentable diet (CTRL) that contained $34.8 \%$ starch (Table 1). Increased concentrations of $\mathrm{CNO}$ led to a quadratic decrease in DMI (Figure 1B) in contrast to the hypothesized linear reduction. On the contrary, feeding $5 \%$ dietary $\mathrm{C}_{14: 0}$ (approximately $19 \%$ of $\mathrm{CNO}$ ) to latelactation dairy cows decreased DMI by $7 \%$ (Odongo et al., 2007). The dietary $\mathrm{C}_{14}$ concentration in the latter experiment was approximately 5 times greater than the respective concentration in 5\%-CNO in the current experiment. The marked depression in DMI we observed was either not due to dietary $\mathrm{C}_{14}$ or due to the difference in multiple of maintenance of $\mathrm{NE}_{\mathrm{L}}$ intake of cows in the current experiment and that of Odongo et al. (2007).

Integration of the results in both current experiments indicated 2 potential mechanisms that influence DMI in ruminants fed CNO. One mechanism appeared to affect DMI after more than $1 \mathrm{~d}$ of feeding of $3 \%$ dietary CNO (Figure 1B) and could be a consequence of DMI regulation via ruminal distention (Allen, 2000). The other mechanism appeared to result in the precipitous

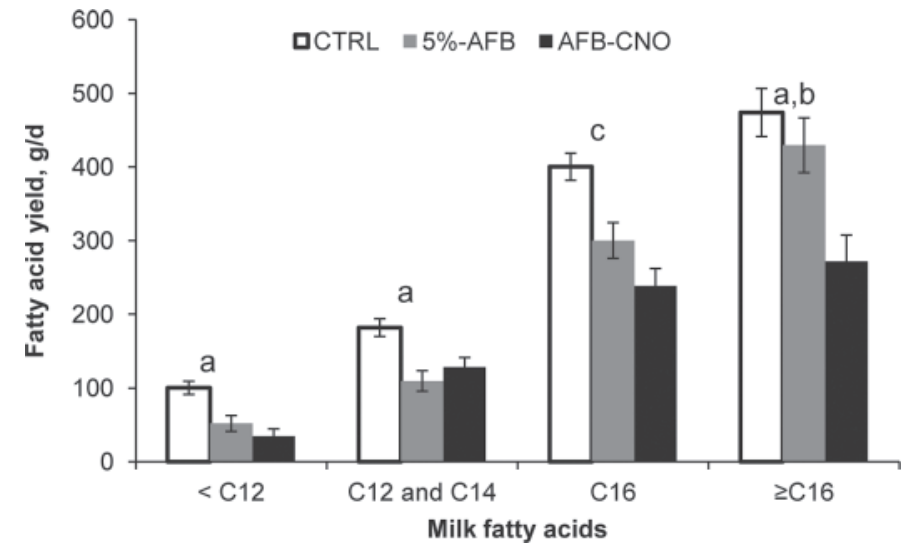

Figure 3. Effects of dietary fat treatments on milk fatty acid secretion (experiment 1). Treatments were control (CTRL); animal fat blend (5\%-AFB); or a 1:1 mixture of AFB and coconut oil (5\%-AFB-CNO). Annotations: $\mathrm{a}=$ effect of fats (CTRL vs. $5 \%$-AFB and $5 \%$-AFB$\mathrm{CNO} ; P<0.02) ; \mathrm{b}=$ effect of fat source $(5 \%$-AFB vs. $5 \%$-AFB-CNO; $P<0.01)$; and $\mathrm{c}=$ interaction of treatment and covariate of preexperimental yield of $\mathrm{C}_{16}(P<0.05)$, where pre-experimental $\mathrm{C}_{16}$ yield related linearly and positively to experimental $\mathrm{C}_{16}$ yield of CTRL-fed cows, but did not relate to experimental $\mathrm{C}_{16}$ in $5 \%$-AFB and $5 \%$-AFBCNO treatment diets.

depression in DMI within $1 \mathrm{~d}$ of feeding equal to or greater than $4 \%$ dietary CNO (Figures $1 \mathrm{~A}$ and $\mathrm{B}$ ) and could relate to the DMI regulation by oxidation of fuels (Allen et al., 2009), gut peptide responses to dietary MCFA, or palatability.

NDF Digestion. Consistent with previous studies (Sutton et al., 1983; Jordan et al., 2006; Reveneau, 2008), we found that $2.5 \%$ dietary CNO (replacing 2.5 percentage units of dietary AFB) decreased NDFD (Table 3), even though NDF intake was depressed. Sut-

Table 6. Effects of dietary fat treatments on net energy intake, milk output, and conversion efficiency (experiment 1)

\begin{tabular}{|c|c|c|c|c|c|c|}
\hline \multirow[b]{2}{*}{ Item } & \multicolumn{3}{|c|}{ Treatment $\mathrm{LSM}^{1}$} & \multirow[b]{2}{*}{ SEM } & \multicolumn{2}{|c|}{$P^{2}<$} \\
\hline & CTRL & $5 \%$-AFB & $5 \%$-AFB-CNO & & $\begin{array}{c}\text { CTRL vs. } \\
5 \%-\mathrm{AFB} \text { and } \\
5 \%-\mathrm{AFB}-\mathrm{CNO}\end{array}$ & $\begin{array}{l}5 \% \text {-AFB vs. } \\
5 \% \text {-AFB-CNO }\end{array}$ \\
\hline \multicolumn{7}{|l|}{ Intake } \\
\hline $\mathrm{NE}_{\mathrm{L}},{ }^{3} \mathrm{Mcal} / \mathrm{d}$ & 49.5 & 49.0 & 44.7 & 2.17 & 0.13 & 0.05 \\
\hline Production & & & & & & \\
\hline Milk $\mathrm{NE}_{\mathrm{L}},{ }^{4} \mathrm{Mcal} / \mathrm{d}$ & 27.9 & 23.9 & 19.9 & 1.13 & 0.01 & 0.03 \\
\hline $\begin{array}{l}\text { Efficiency } \\
\text { NE }_{\text {L Milk/DE intake }}\end{array}$ & 0.39 & 0.32 & 0.32 & 0.025 & 0.10 & $\mathrm{NS}^{5}$ \\
\hline
\end{tabular}

${ }^{1}$ Treatments were CTRL $=$ control; $5 \%$-AFB $=$ animal fat blend; $5 \%$-AFB-CNO = a 1:1 mixture of AFB and coconut oil.

${ }^{2}$ Orthogonal contrasts for dietary fat and source of dietary fat (chain length of fatty acids).

${ }^{3} \mathrm{NE}_{\mathrm{L}(\text { intake) }}=0.703 \times \mathrm{ME}_{\text {(intake) }}-0.19+\left(0.097 \times \mathrm{ME}_{(\text {intake) }}+0.19\right) / 97 \times[($ ether extract $)-3] ; \mathrm{ME}_{\text {(intake) }}=(1.01$ $\left.\times \mathrm{DE}_{(\text {intake) }}-0.45\right)+0.0046 \times[($ ether extract $)-3]$, where $\mathrm{DE}=$ digestible energy $(\mathrm{NRC}, 2001)$; from actual measurement (Table 2).

${ }^{4} \mathrm{NE}_{\mathrm{L}(\text { milk })}(\mathrm{Mcal} / \mathrm{d})=$ milk yield $(\mathrm{kg}) \times[0.0929 \times($ milk fat $)+0.0563 \times($ milk true protein $)+0.0395 \times($ milk lactose)] (NRC, 2001).

${ }^{5} \mathrm{NS}=$ nonsignificant $(P>0.20)$. 
ton et al. (1983) noted that dietary CNO depressed ruminal NDFD greater than total-tract NDFD due to limited compensatory lower tract NDF digestion. Thus, dietary CNO likely decreased ruminal NDFD even more than was evident from the total-tract digestibility in the current experiment. The observed depression in NDFD in 5\%-AFB-CNO fed cows was without a concurrent effect on apparent total-tract starch and CP digestibilities.

Ruminal distention is one mechanism that regulates DMI, and the effect of ruminal fill on DMI increases with the magnitude of intake and of fill effect of the diet (Allen, 2000). The depression in amount of NDF digested in the total tract explained most of the decrease in NDF intake (Table 3). In contrast, intake of NDF that subsequently was not digested was similar for all treatments ( 3.5 to $3.7 \mathrm{~kg} / \mathrm{d}$ ). However, it is doubtful that ruminal distention was the sole, or perhaps primary, regulator of DMI for 2 reasons. First, cows decreased their DMI $8.1 \mathrm{~kg}$ within $1 \mathrm{~d}$ after being switched from CTRL to $5 \%$-CNO, and cows increased their DMI $4.1 \mathrm{~kg}$ within $1 \mathrm{~d}$ after being switched back from 5\%-CNO to CTRL diet in experiment 1 (Figure 1A). These immediate and precipitous DMI responses were likely not due to DMI regulation solely by ruminal distention. However, the $10 \%$ difference in DMI between cows fed CTRL and cows switched from 5\%-CNO to CTRL during the 5 -d period following the dietary switchback may be a carryover effect influenced by increased ruminal fill. Second, cows fed 2\%-CNO in experiment 2 decreased DMI from 3 to $6 \mathrm{~d}$ following introduction of treatments; however, DMI reduction occurred faster after introduction of $3 \%$-CNO (2 d). In contrast, the DMI reduction in 4\%CNO was instantaneous (within $1 \mathrm{~d}$ ). The delayed DMI reduction in cows fed $2 \%$-CNO, or especially $3 \%$-CNO, in experiment 2 may have been in response to increased ruminal fill over 2 to $6 \mathrm{~d}$. Presumably, the decrease in ruminal NDFD and subsequent increase in ruminal fill was faster for $3 \%$-CNO than for $2 \%$-CNO. Conceivably, depression in ruminal NDFD may have accounted for a portion of the decrease in DMI. Alternatively, the DMI response in cows fed $2 \%$-CNO could be due to a shift in DMI independent to treatment. Nonetheless, we speculate that the DMI reduction due to ruminal fill encompassed only a small proportion of the overall reduction in $4 \%$ and $5 \%$-CNO treatment diets.

Oxidation of Metabolic Fuels. The precipitous reduction in DMI within $1 \mathrm{~d}$ could be due to an increase in endogenous oxidation of metabolic fuels (Allen et al., 2009). Medium-chain FA differ from LCFA in mode of digestion, absorption, transport (Bloom et al., 1951), cellular uptake (Guillot et al., 1993), and rate and control of oxidation. Oxidation of MCFA in the liver is high and unregulated, in contrast to oxidation of LCFA (McGarry et al., 1977). Unregulated oxidation of MCFA may increase the oxidative state, increase the satiety signal, and consequently decrease DMI.

Cows in the current experiments consumed a highstarch diet. Presumably, the concurrent high degradation of ruminal starch increased the propionate generated and absorbed, and subsequently increased the oxidative state of the liver (Allen et al., 2009). This may explain the greater DMI depression we observed in cows fed $5 \%$-CNO ( $40 \%$ on d 4) compared with Reveneau $(2008 ; 26 \%)$. The high availability of propionate may have exacerbated the DMI depression of MCFA in the current experiments.

Gut Peptide Responses. Responses in plasma gut peptide concentrations to dietary MCFA have not been reported in ruminants. However, dietary FA longer than or equal to $\mathrm{C}_{12}$ are secretagogues of gut peptides in humans (Feltrin et al., 2004). In lactating dairy cows, dietary unsaturated LCFA (mostly $\mathrm{C}_{16}$ and $\mathrm{C}_{18}$ ) increased plasma concentrations of gut peptides (Choi et al., 2000; Relling and Reynolds, 2007; Bradford et al., 2008) and corresponded to decreases in DMI. Also, dietary $\mathrm{C}_{12}$ elicited an increase in plasma gut peptide concentrations and decreased duodenal contractions in humans (Feltrin et al., 2004). Thus, it is possible that dietary CNO (approximately $41 \% \mathrm{C}_{12}$ ) evokes a similar response in plasma gut peptide concentrations in cattle that should be studied further.

Palatability. Others have speculated that dietary MCFA or CNO affects palatability (or acceptability) in ruminants (Külling et al., 2002; Hristov et al., 2011). Palatability can be assessed by monitoring feeding behaviors, such as meal bouts, meal sizes, and eating rates; nonetheless, this has not been reported, to our knowledge, in cattle fed MCFA. Cows fed 2 or $3 \%$ CNO decreased DMI following 2 to $6 \mathrm{~d}$ of treatment, in contrast to the immediate DMI reduction in cows fed $4 \%$-CNO in experiment 2. Therefore, it seems unlikely that palatability of CNO affects DMI, at least in diets containing as much as 3\% CNO.

Effects of Animal Fat Blend. Orthogonal contrasts in experiment 1 were not designed to test effects of AFB and thus, no direct statistical comparison of CTRL and 5\%-AFB was made. When AFB was substituted for ground corn grain at $5 \%$ of the dietary DM, cows consumed less DM, but maintained energy intake (GE, DE, and $\mathrm{NE}_{\mathrm{L}}$; Tables 3 and 6). Added dietary fats often decrease DMI, but not necessarily caloric intake (Palmquist, 1994). Despite the similar energy intakes in CTRL and AFB, daily $\mathrm{NE}_{\mathrm{L}}$ milk output was $4.0 \mathrm{Mcal} /$ cow less for cows fed 5\%-AFB than CTRL (Table 6). Harvatine and Allen (2006) noted that cows fed additional unsaturated FA partitioned less dietary energy toward milk energy and more dietary energy 
toward BW gain. This may have occurred in the current experiment; however, it was short-term and BW were not recorded.

Apparent total-tract NDFD was 3.6 percentage points lower for 5\%-AFB fed cows than those fed CTRL even though cows fed 5\%-AFB consumed less NDF (overall and from forage). Presumably, ruminal rate of NDF digestion was lower in cows fed 5\%-AFB than CTRL. Overall, dietary tallow within a concentration range of 2.0 to $5.6 \%$ of dietary DM decreases NDFD, based on a meta-analysis (Onetti and Grummer, 2004).

Cows fed 5\%-AFB maintained DE intake compared with CTRL-fed cows. This, however, does not exclude the potential for changes in DMI regulation. Cows fed $5 \%$-AFB consumed less starch and presumably produced less ruminal propionate. This may have alleviated DMI depression from the high-starch diet (Allen et al., 2009), but may have been counterbalanced by an increased plasma gut peptide concentration from dietary unsaturated FA (Relling and Reynolds, 2007). As a result, no detectable net change occurred in $\mathrm{DE}$ intake from the dietary inclusion of 5\%-AFB.

\section{Milk Composition}

Milk fat concentration was low $(3.10 \%)$, and milk fat yield was likely depressed in CTRL. Most likely, MFD occurred as was expected from the highly fermentable diet (34.8\% starch; Table 1). The 5\%-AFB and 5\%-AFB-CNO diets had lower starch concentrations than CTRL, but nonetheless exacerbated MFD (Figures 2A and B). This MFD is consistent with other reports for dietary tallow (Onetti and Grummer, 2004) and MCFA (Külling et al., 2002; Reveneau, 2008). In our experiment, extent of MFD corresponded to increased concentrations of $\mathrm{C}_{18: 2 \text { trans-10,cis-12 }}$ in milk fat, suggesting alterations in ruminal biohydrogenation pathways (Lock et al., 2006). Interestingly, milk fat concentrations of $\mathrm{C}_{18: 2}$ trans-10.cis-12 increased numerically with the partial substitution of CNO for AFB, although the amount of dietary precursors (sum of $\mathrm{C}_{18: 2}$ and $\mathrm{C}_{18: 3}$ ) consumed were less in 5\%-AFB-CNO than 5\%-AFB treatment. Therefore, ruminal outflow of $\mathrm{C}_{18: 2}$ trans-10,cis-12 was not necessarily a linear response to dietary intake of $\mathrm{C}_{18: 2}$ and $\mathrm{C}_{18: 3}$, but more likely the result of several dietary factors (Lock et al., 2006). The integration of amounts of NDF and starch concurrently ruminally digested may have affected pathways of biohydrogenation in the current experiment.

The depressions in milk fat yield and concentration with dietary fat supplementation was found in cows with greater milk fat concentration or yield during the pre-experimental period (Figures $2 \mathrm{~A}$ and $\mathrm{B}$ ). In turn, the decrease in milk fat concentration or yield was minimal when respective values were already low during pre-experimental period. Similarly, de Veth et al. (2004) reported that milk fat concentration of dairy cows can reach a minimum beyond which a further decrease in milk fat concentration appears impossible. This minimum milk fat concentration was approximately 1.5 to $2 \%$ in de Veth et al. (2004) and was similar in the present study. We did not observe differences in milk fat yield and concentration between 5\%-AFB and 5\%-AFB-CNO, which may have been due to low milk fat concentration in cows fed 5\%-AFB. Given the minimum milk fat concentration, potential differences in milk fat yield or concentration between dietary AFB and CNO could have been greater, if CTRL (without added fat) did not cause MFD.

Dietary fat treatments affected milk FA profile in experiment 1, similar to studies in which tallow was added to a highly fermentable diet (Onetti et al., 2004) or MCFA were fed (Reveneau, 2008; Hristov et al., 2011). Recovery efficiencies of individual dietary FA in milk fat potentially relate to FA metabolism. Dietary CNO generally decreases concentrations of $\mathrm{C}_{8}$ and $\mathrm{C}_{10}$ in milk FA, although these FA account for approximately $17 \%$ of CNO. In contrast, $\mathrm{C}_{12}$ and $\mathrm{C}_{14}$ concentrations in milk fat increased or sustained, respectively, when CNO replaced corn grain in the diet (Table 5), even though de novo synthesis of milk FA was decreased. Approximately 13 and $74 \%$ of $\mathrm{C}_{12}$ and $\mathrm{C}_{14}$ from dietary CNO, respectively, were recovered in milk fat. This was based on the assumption that CNO was 93\% FA with an average chain length of $13 \mathrm{C}$. Reveneau (2008) detected comparable recovery of $22 \%$ of dietary $\mathrm{C}_{12}$ and $85 \%$ of dietary $\mathrm{C}_{14}$ in milk fat. The transfer efficiencies of dietary $\mathrm{C}_{12}$ and $\mathrm{C}_{14}$ into $\mathrm{C}_{12}$ and $\mathrm{C}_{14}$ in milk fat are likely elevated, as limited de novo synthesis of these milk FA still occurred. Nonetheless, the recovery of dietary $\mathrm{C}_{8}$ to $\mathrm{C}_{14}$ in milk fat mirrored the presumed transport, and hepatic uptake and $\beta$-oxidation of individual FA $\left(\mathrm{C}_{8}=\mathrm{C}_{10}>\mathrm{C}_{12}>\mathrm{C}_{14}\right)$. Approximately 40 and $75 \%$ of absorbed dietary $\mathrm{C}_{12}$ and $\mathrm{C}_{14}$, respectively, are transported in the lymph system in rats (Bloom et al., 1951), and these FA are exposed to the mammary gland before the liver on the first pass. In contrast, more than $90 \%$ of absorbed dietary $\mathrm{C}_{8}$ and $\mathrm{C}_{10}$ are transported in the blood stream (Bloom et al., 1951) and readily taken up by the liver (Guillot et al., 1993). Moreover, hepatic uptake of $\mathrm{C}_{14: 0}$ is low in rats (Wang and Koo, 1993). As a result, the mammary gland is exposed to each unit of absorbed dietary $\mathrm{C}_{14: 0}$ several times, which may further explain the high recovery of dietary $\mathrm{C}_{14}$ in milk fat in the current experiment.

Commonly, $\mathrm{C}_{16}$ is the breakpoint between de novo synthesis of FA and uptake of preformed FA by the mammary gland (Bauman and Griinari, 2001). We 
included a fourth yield category of $\mathrm{C}_{12}$ to $\mathrm{C}_{14}$ milk FA (Figure 3), because preformed FA from the diet most likely contributed to this pool of FA in cows fed $5 \%$-AFB-CNO, as discussed above. Thus, the mammary gland presumably utilized de novo synthesis as well as absorbed preformed $\mathrm{C}_{12}$ to $\mathrm{C}_{14}$ from the $5 \%$-AFB-CNO diet. Decreased yields of de novo and preformed FA in milk in the current experiment are similar to those reviewed by Harvatine et al. (2009). Cows fed 5\%-AFB$\mathrm{CNO}$ had a greater yield reduction in preformed milk FA $\left(>\mathrm{C}_{16}\right)$ than those fed $5 \%$-AFB, similar to observations by Reveneau (2008). Cows fed CTRL consumed approximately $550 \mathrm{~g} / \mathrm{d}$ less of dietary $\mathrm{FA}\left(>\mathrm{C}_{16}\right)$, but yielded $202 \mathrm{~g} / \mathrm{d}$ more of milk FA $\left(>\mathrm{C}_{16}\right)$ than did cows fed 5\%-AFB-CNO (Figure 3). Therefore, it is unlikely that the yield reduction in the current study was due to a lack of preformed FA $\left(>\mathrm{C}_{16}\right)$. Alternatively, dietary MCFA affects directly or indirectly (via increase in $\mathrm{C}_{18: 2}$ trans-10,cis-12 from ruminal biohydrogenation; Harvatine et al., 2009) uptake or secretion by the mammary gland of preformed FA more than does dietary unsaturated LCFA. Indeed, cows fed 5\%-AFB-CNO consumed less digestible energy. Thus, more preformed LCFA were presumably utilized by nonmammary tissues to account for lower availability of glucose from dietary precursors in $5 \%$-AFB-CNO than in 5\%-AFB.

The negative response in milk lactose concentration to dietary MCFA that we observed has been reported previously (Faciola et al., 2008; Reveneau, 2008). Simultaneous with this response, the concentration of milk citrate increased with dietary fat treatments in the current experiment (Table 4). Garnsworthy et al. (2006) speculated that citric acid accumulates during MFD in epithelia cells of the mammary gland because of decreased de novo synthesis of milk FA. Intracellular citric acid is secreted in milk (Linzell et al., 1976). Additionally, citrate is a strong regulator of osmolaric pressure in milk. As a result, an increase in milk citrate concentration apparently compensates for the decreased concentrations of milk lactose during MFD to maintain overall solute concentration in milk.

\section{General Discussion}

The lower-than-expected EE concentration and GE density in 5\%-AFB-CNO and 5\%-CNO may have been due in part to the stickiness of the CNO-containing concentrate premixes. As a result, portions of dietary CNO could have stuck to the equipment during feeding or feed sample preparation. Presumably, the observed stickiness of CNO-containing concentrate premixes were specifically due to the MCFA in CNO, as measured MCFA concentrations in FA in 5\%-AFB-CNO were below the calculated concentrations. A portion of these MCFA was likely lost during feed and sample preparations and may have accounted for lower analyzed EE concentration and GE density.

We intended to evaluate the effects of dietary CNO on lactational performance of dairy cows. Others have proposed that dietary MCFA (60\% of CNO) can mitigate enteric methane emissions and improve conversion efficiency of dietary $\mathrm{N}$ into milk protein (Hristov and Jouany, 2005). We chose a highly fermentable, highstarch diet, because of the greater potential to mitigate enteric methane production (McAllister et al., 1996) and to assess potential practical limitations of dietary MCFA in ruminant diets, such as depressions in DMI, NDFD, and milk fat, and changes in milk FA profile. The highly fermentable diet did not help to alleviate these limitations in the current experiments. Furthermore, $2.5 \%$ dietary CO (5\%-AFB-CNO) did not improve $\mathrm{N}$ efficiency and dietary fats including $5 \%$-AFB$\mathrm{CNO}$ reduced milk protein yield. No scientific report to our knowledge has yet shown an increase in $\mathrm{N}$ efficiency in lactating dairy cows fed added MCFA. Dietary CNO does not appear to be a commercially useful feed ingredient for lactating dairy cows within the limitations of the current study (e.g., abrupt introduction of high CNO concentration, high dietary starch concentration). This might change if dietary CNO mitigated enteric methane emissions, and the mitigation generated revenue (e.g., via carbon credits) to compensate for losses in lactational performance. Nonetheless, the magnitude and multitude of losses (DMI, NDFD, SCMY, and milk component yields) and undesirable changes in milk FA profile appear stupendous at present.

\section{CONCLUSIONS}

Responses in lactating dairy cows to dietary CNO, a source of MCFA, differ greatly from responses to AFB in a high-starch diet. Abruptly introduced dietary concentrations of 4 and 5\% CNO severely decreased DMI and energy intake. Moreover, replacing 2.5 percentage units of AFB with CNO depressed total-tract NDFD. The effect of abruptly introduced, high concentrations of $\mathrm{CNO}$ on DMI occurred in 2 stages. Dietary CNO greater than or equal to $4 \%$ in the diet depressed DMI precipitously (within $1 \mathrm{~d}$ ). Dietary CNO concentrations of 2 and $3 \%$ decreased DMI after several days. Dietary $5 \%$-AFB and 5\%-AFB-CNO decreased milk yield and exacerbated MFD. An apparent biological minimum of 1.5 to $2.0 \%$ milk fat prohibited detection of potential differences in milk fat yield and concentration between 5\%-AFB and 5\%-AFB-CNO. Furthermore, cows fed $5 \%$-AFB-CNO had decreased SCM yield and yield of preformed milk FA $\left(>\mathrm{C}_{16}\right)$ compared with $5 \%$-AFB. These results illustrate the practical limitations of 
dietary $\mathrm{CNO}$ because of decreased lactational performance and NDFD in highly fermentable diets with abrupt dietary introduction of CNO.

\section{ACKNOWLEDGMENTS}

We thank West Central Cooperative (Ralston, IA) for the donation of SoyPLUS. We also acknowledge the support of R. E. Kreft and the farm crew at the Michigan State University Dairy Teaching and Research Center (East Lansing) and of B. Story at the Michigan State University Feed Mill. We are grateful for the technical assistance of D. G. Main, L. E. Gault, and O. N. Genther, and of T. H. Herdt and J. A. Zyskowski (Nutrition Laboratory at the Diagnostic Center for Population Animal Health at Michigan State University).

\section{REFERENCES}

Allen, M. S. 2000. Effects of diet on short-term regulation of feed intake by lactating dairy cattle. J. Dairy Sci. 83:1598-1624.

Allen, M. S., B. J. Bradford, and M. Oba. 2009. The hepatic oxidation theory of the control of feed intake and its application to ruminants. J. Anim. Sci. 87:3317-3334.

AOAC. 1990. Official Methods of Analysis. Vol. 2. 15th ed. AOAC, Arlington, VA.

Bauman, D. E., and J. M. Griinari. 2001. Regulation and nutritional manipulation of milk fat: Low-fat milk syndrome. Livest. Prod. Sci. $70: 15-29$

Bloom, B., I. L. Chaikoff, and W. O. Reinhardt. 1951. Intestinal lymph as pathway for transport of absorbed fatty acids of different chain lengths. Am. J. Physiol. 166:451-455.

Bradford, B. J., and M. S. Allen. 2004. Milk fat responses to a change in diet fermentability vary by production level in dairy cattle. J. Dairy Sci. 87:3800-3807.

Bradford, B. J., K. J. Harvatine, and M. S. Allen. 2008. Dietary unsaturated fatty acids increase plasma glucagon-like peptide- 1 and cholecystokinin and may decrease premeal ghrelin in lactating dairy cows. J. Dairy Sci. 91:1443-1450.

Choi, B.-R., D. L. Palmquist, and M. S. Allen. 2000. Cholecystokinin mediates depression of feed intake in dairy cattle fed high fat diets. Domest. Anim. Endocrinol. 19:159-175.

Crampton, E. W., and L. E. Lloyd. 1951. Studies with sheep on the use of chromic oxide as an index of digestibility of ruminant rations. J. Nutr. 45:319-327.

de Veth, M. J., J. M. Griinari, A.-M. Pfeiffer, and D. E. Bauman. 2004. Effect of CLA on milk fat synthesis in dairy cows: Comparison of inhibition by methyl esters and free fatty acids, and relationships among studies. Lipids 39:365-372.

Dohme, F., A. Machmüller, F. Sutter, and M. Kreuzer. 2004. Digestive and metabolic utilization of lauric, myristic and stearic acid in cows, and associated effects on milk fat quality. Arch. Anim. Nutr. 58:99-116.

Faciola, A. P., G. A. Broderick, A. N. Hristov, and J. A. Pires. 2008. Effect of four levels of lauric acid on ruminal protozoa, milk production and composition in dairy cows. J. Dairy Sci. 91(E-Suppl. 1):76. (Abstr.)

Feltrin, K. L., T. J. Little, J. H. Meyer, M. Horowitz, A. J. P. M. Smout, J. Wishart, A. N. Pilichiewicz, T. Rades, I. M. Chapman, and C. Feinle-Bisset. 2004. Effects of intraduodenal fatty acids on appetite, antropyloroduodenal motility, and plasma CCK and GLP-1 in humans vary with their chain length. Am. J. Physiol. Regul. Integr. Comp. Physiol. 287:R524-R533.
Garnsworthy, P. C., L. L. Masson, A. L. Lock, and T. T. Mottram. 2006. Variation of milk citrate with stage of lactation and de novo fatty acid synthesis in dairy cows. J. Dairy Sci. 89:1604-1612.

Goering, H. H., and P. J. Van Soest. 1970. Forage Fiber Analysis (Apparatus, Reagents, Procedures, and Some Applications). Agric. Handbook No. 379. USDA-ARS, Washington, DC.

Grundy, S. M. 1994. Influence of stearic acid on cholesterol metabolism relative to other long-chain fatty acids. Am. J. Clin. Nutr. 60(Suppl.):986S-990S.

Guillot, E., P. Vaugelade, P. Lemarchal, and A. Rérat. 1993. Intestinal absorption and liver uptake of medium-chain fatty acids in nonanaesthetized pigs. Br. J. Nutr. 69:431-442.

Hach, C. C., B. K. Bowden, A. B. Kopelove, and S. V. Brayton. 1987. More powerful peroxide Kjeldahl digestion method. J. Assoc. Off. Anal. Chem. 70:783-787.

Harvatine, K. J., and M. S. Allen. 2006. Effects of fatty acid supplements on milk yield and energy balance of lactating dairy cows. J. Dairy Sci. 89:1081-1091.

Harvatine, K. J., Y. R. Boisclair, and D. E. Bauman. 2009. Recent advances in the regulation of milk fat synthesis. Animal 3:40-54.

Hollmann, M., M. S. Allen, and D. K. Beede. 2011. Diet fermentability influences lactational performance responses to corn distillers grains: A meta-analysis. J. Dairy Sci. 94:2007-2021.

Hristov, A. N., and J.-P. Jouany. 2005. Factors affecting the efficiency of nitrogen utilization in the rumen. Pages 117-166 in Nitrogen and Phosphorus Nutrition of Cattle and Environment. A. N. Hristov and E. Pfeffer, ed. CAB International, Wallingford, UK.

Hristov, A. N., C. Lee, T. Cassidy, M. Long, K. Heyler, B. A. Corl, and R. Foster. 2011. Effects of lauric and myristic acids on ruminal fermentation, production, and milk fatty acid composition in lactating dairy cows. J. Dairy Sci. 94:382-395.

Jordan, E., D. K. Lovett, M. Hawkins, J. J. Callan, and F. P. O'Mara. 2006. The effect of varying levels of coconut oil on intake, digestibility and methane output from continental cross beef heifers. Anim. Sci. 82:859-865.

Karkalas, J. 1985. An improved enzymatic method for the determination of native and modified starch. J. Sci. Food Agric. 36:10191027.

Külling, D. R., F. Dohme, H. Menzi, F. Sutter, P. Lischer, and M. Kreuzer. 2002. Methane emissions of differently fed dairy cows and corresponding methane and nitrogen emissions from their manure during storage. Environ. Monit. Assess. 79:129-150.

Linzell, J. L., T. B. Mepham, and M. Peaker. 1976. The secretion of citrate into milk. J. Physiol. 260:739-750.

Lock, A. L., T. R. Overton, K. J. Harvatine, J. G. Giesy, and D. E. Bauman. 2006. Milk fat depression: Impact of dietary components and their interaction during rumen fermentation. Pages 75-85 in Proc. Cornell Nutr. Conf. Feed Manuf. Cornell University, Ithaca, NY.

McAllister, T. A., E. K. Okine, G. W. Mathison, and K. J. Cheng. 1996. Dietary, environmental and microbiological aspects of methane production in ruminants. Can. J. Anim. Sci. 76:231-243.

McGarry, J. D., G. P. Mannaerts, and D. W. Foster. 1977. A possible role for malonyl-CoA in the regulation of hepatic fatty acid oxidation and ketogenesis. J. Clin. Invest. 60:265-270.

Mollering, H. 1989. Citrate. Pages 2-12 in Methods of Enzymatic Analysis. 3rd ed. Vol. VII. H. U. Bergmeyer, ed. VCH Publishers (UK) Ltd., Cambridge, UK.

NRC. 2001. Nutrient requirements of dairy cattle. 7th rev. ed. Natl. Acad. Sci., Washington, DC.

Odongo, N. E., M. M. Or-Rashid, E. Kebreab, J. France, and B. W. McBride. 2007. Effect of supplementing myristic acid in dairy cow rations on ruminal methanogenesis and fatty acid profile in milk. J. Dairy Sci. 90:1851-1858.

Onetti, S. G., and R. R. Grummer. 2004. Response of lactating cows to three supplemental fat sources as affected by forage in the diet and stage of lactation: A meta-analysis of literature. Anim. Feed Sci. Technol. 115:65-82.

Onetti, S. G., S. M. Reynal, and R. R. Grummer. 2004. Effect of alfalfa forage preservation method and particle length on performance 
of dairy cows fed corn silage-based diets and tallow. J. Dairy Sci. 87:652-664.

Onetti, S. G., R. D. Shaver, M. A. McGuire, and R. R. Grummer. 2001. Effect of type and level of dietary fat on rumen fermentation and performance of dairy cows fed corn silage-based diets. J. Dairy Sci. 84:2751-2759.

Palmquist, D. L. 1994. The role of dietary fats in efficiency of ruminants. J. Nutr. 124(Suppl.):1377S-1382S.

Relling, A. E., and C. K. Reynolds. 2007. Feeding rumen-inert fats differing in their degree of saturation decreases intake and increases plasma concentrations of gut peptides in lactating dairy cows. J. Dairy Sci. 90:1506-1515.

Reveneau, C. 2008. Dietary source and availability of fatty acids to manipulate ruminal protozoa, metabolism of fat, and milk fatty acid profile in lactating dairy cows. PhD Diss. The Ohio St. Univ., Columbus.

Staples, C. R. 2006. Milk fat depression in dairy cows-Influence of supplemental fats. Pages 122-138 in Proc. Florida Rum. Nutr. Symp., Gainesville, FL. University of Florida, Gainesville.

Sukhija, P. S., and D. L. Palmquist. 1988. Rapid method for determination of total fatty acid content and composition of feedstuffs and feces. J. Agric. Food Chem. 36:1202-1206.
Sutton, J. D., R. Knight, A. B. McAllan, and R. H. Smith. 1983. Digestion and synthesis in the rumen of sheep given diets supplemented with free and protected oils. Br. J. Nutr. 49:419-432.

Tyrrell, H. F., and J. T. Reid. 1965. Prediction of the energy value of cow's milk. J. Dairy Sci. 48:1215-1223.

Van Soest, P. J., J. B. Robertson, and B. A. Lewis. 1991. Methods for dietary fiber, neutral detergent fiber, and nonstarch polysaccharides in relation to animal nutrition. J. Dairy Sci. 74:3583-3597.

Verdi, R. J., D. M. Barbano, M. E. Dellavalle, and G. F. Senyk. 1987. Variability in true protein, casein, nonprotein nitrogen, and proteolysis in high and low somatic cell milks. J. Dairy Sci. 70:230-242.

Wang, S., and S. I. Koo. 1993. Plasma clearance and hepatic utilization of stearic, myristic and linoleic acids introduced via chylomicrons in rats. Lipids 28:697-703.

Williams, C. H., D. J. David, and O. Iismaa. 1962. The determination of chromic oxide in feces samples by atomic absorption spectrophotometry. J. Agric. Sci. 59:381-385. 